\title{
Recent Progress and Trends in the Development of Microbial Biofuels from Solid Waste-A Review
}

\author{
Ulugbek Azimov ${ }^{1, *(D)}$, Victor Okoro ${ }^{1}$ and Hector H. Hernandez ${ }^{2}$ (D) \\ 1 Faculty of Engineering and Environment, Northumbria University, Newcastle upon Tyne NE1 8ST, UK; \\ v.okoro@northumbria.ac.uk \\ 2 Department of Biomedical Engineering, Khalifa University, \\ Abu Dhabi P.O. Box 127788, United Arab Emirates; hhhernandez@me.com \\ * Correspondence: ulugbek.azimov@northumbria.ac.uk
}

check for updates

Citation: Azimov, U.; Okoro, V.; Hernandez, H.H. Recent Progress and Trends in the Development of Microbial Biofuels from Solid Waste-A Review. Energies 2021, 14, 6011. https://doi.org/10.3390/ en14196011

Academic Editor: Attilio Converti

Received: 19 August 2021

Accepted: 15 September 2021

Published: 22 September 2021

Publisher's Note: MDPI stays neutral with regard to jurisdictional claims in published maps and institutional affiliations.

Copyright: (c) 2021 by the authors. Licensee MDPI, Basel, Switzerland. This article is an open access article distributed under the terms and conditions of the Creative Commons Attribution (CC BY) license (https:/ / creativecommons.org/licenses/by/ $4.0 /)$.

\begin{abstract}
This review covers the recent progress in the design and application of microbial biofuels, assessing the advancement of genetic engineering undertakings and their marketability, and lignocellulosic biomass pretreatment issues. Municipal solid waste (MSW) is a promising sustainable biofuel feedstock due to its high content of lignocellulosic fiber. In this review, we compared the production of fatty alcohols, alkanes, and n-butanol from residual biogenic waste and the environmental/economic parameters to that of conventional biofuels. New synthetic biology tools can be used to engineer fermentation pathways within micro-organisms to produce long-chain alcohols, isoprenoids, long-chain fatty acids, and esters, along with alkanes, as substitutes to petroleum-derived fuels. Biotechnological advances have struggled to address problems with bioethanol, such as lower energy density compared to gasoline and high corrosive and hygroscopic qualities that restrict its application in present infrastructure. Biofuels derived from the organic fraction of municipal solid waste (OFMSW) may have less environmental impacts compared to traditional fuel production, with the added benefit of lower production costs. Unfortunately, current advanced biofuel production suffers low production rates, which hinders commercial scaling-up efforts. Microbial-produced biofuels can address low productivity while increasing the spectrum of produced bioenergy molecules.
\end{abstract}

Keywords: advanced biofuels; bacterial fuels; synthetic biology; organic waste biomass; pretreatment; climate change; greenhouse gas emissions

\section{Introduction}

Transportation fuel is responsible for a considerable amount of global greenhouse gas emissions. The transport sector consumes $60 \%$ of the global oil production and is estimated to rise from 85 million barrels to 104 million barrels per day by 2030 due to population growth, industrialization of developing countries, and increased affluence [1]. The clean energy mandate to generating biofuels from sustainable biomass is needed to offset fossil fuels use that affects climate change [1].

Currently, bioethanol, the most used biofuel, is derived from either corn or sugar and is considered a first-generation biofuel [2]. However, bioethanol-blended fuels have adverse properties due to their lower energy content and being hygroscopic in nature, thus limiting its use in transportation [2]. Besides, it is miscible in water and corrosive. The drawbacks of first-generation renewable fuels led to the development of second-generation biofuels [3]. One such process based on Fischer-Tropsch conversion produces advanced liquid aviation and diesel fuels known as synthetic paraffinic kerosenes (SPKs) from biomass [4,5]. The large-scale use of second-generation biofuels is restricted by the availability of feedstock [6].

Therefore, the limitations of first- and second-generation biofuels have driven the development of biofuels from abundant energy-rich nonfood feedstock such as organic waste and wastewater [6]. Particularly, European nations are increasingly focusing on agronomic cellulosic waste and waste from forests to form renewable biofuels [7]. Furthermore, 
excess food waste in Asian countries can provide additional feedstock for the generation of superior biofuels [8].

Microbial-derived biofuels present an opportunity to produce renewable biofuels from the organic fraction of municipal solid waste (OFMSW). The challenge is to develop microbe strains that can convert the OFMSW to drop-in biofuels that are anatomically and chemically analogous to mainstream fuels. However, for biofuel production and usage, it will be possible to achieve a net carbon dioxide emissions balance because the carbon is part of the cycle, while fossil fuels give rise to a net addition of carbon dioxide to the atmosphere, as shown in Figure 1 [9].

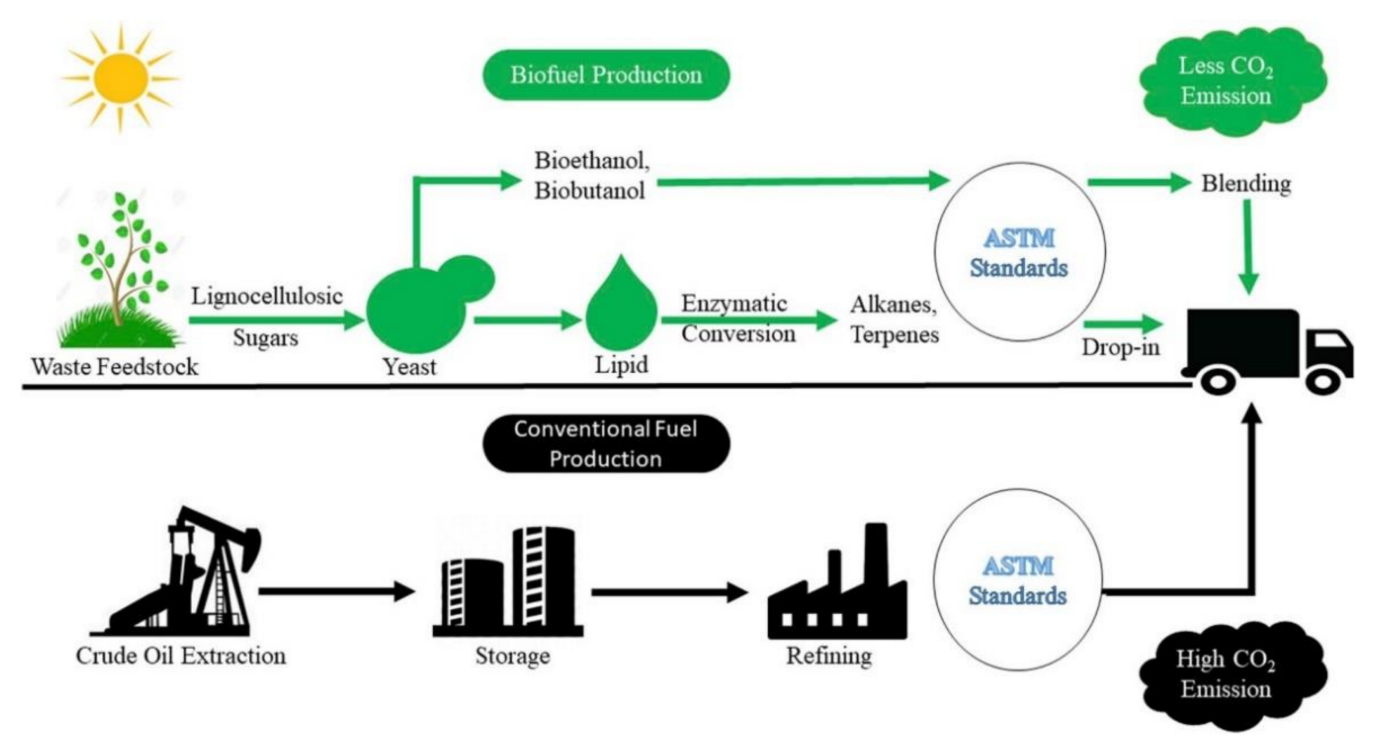

Figure 1. Conventional oil and biofuels net production pathways. Reprint with permission [9]; 2020, Elsevier.

The use of synthetic biology tools allows for the engineering of microbes to convert biomass and waste and control carbon flows for desired biofuels, as shown in Figure 2. Recombinant enzymes are accessible from a wide range of microorganisms and may even be produced heterologously in a designed host organism [10]. Genetic recombination techniques for the introduction of selected metabolic pathways into microorganisms such as Escherichia coli and Saccharomyces cerevisiae can be used to increase the production level of different advanced biofuel precursors [10].

However, the development of industrial-scale nonethanol sustainable biofuels is a more challenging task than that of ethanol production. As short-term economic forces are challenging for industrial development, the need for strategies to enhance biofuel performance and productivity in engineered microbial strains is crucial. In addition, microbial product inhibition, which adversely impact yield, efficiency, and operability, is one of the biggest obstacles for new bioprocesses [11,12].

The microbial production of biofuels utilizes four key metabolic pathways: the alcohol, fatty acid, isoprenoid, and alkane pathways. Additionally, the polyketide synthesis pathway has recently been investigated as an additional metabolic pathway to produce biofuel precursors [13]. Microbial biofuels production can utilize a variety of abundant underutilized carbon sources, such as algal biomass, greenhouse gasses, lignocellulose, carbon monoxide, and carbon dioxide. Residue from feedstock, such as lignocellulose that contains almost 70\% sugar, is the most easily obtainable universal biomass [12]. However, these sugars need to undergo chemical and physical pretreatment prior to the release of sugars for microbial fermentation. The conversion of atmospheric $\mathrm{CO}_{2}$ into biofuels may be viable by carbon fixation through either the Wood-Ljungdahl pathway or through photosynthetic pathways. Carbon monoxide, derived from the thermal ignition of lignocellulosic 
biomass and plentiful in steel-mill flu fumes, can be assimilated by microorganisms into high-bioenergy molecules [12].

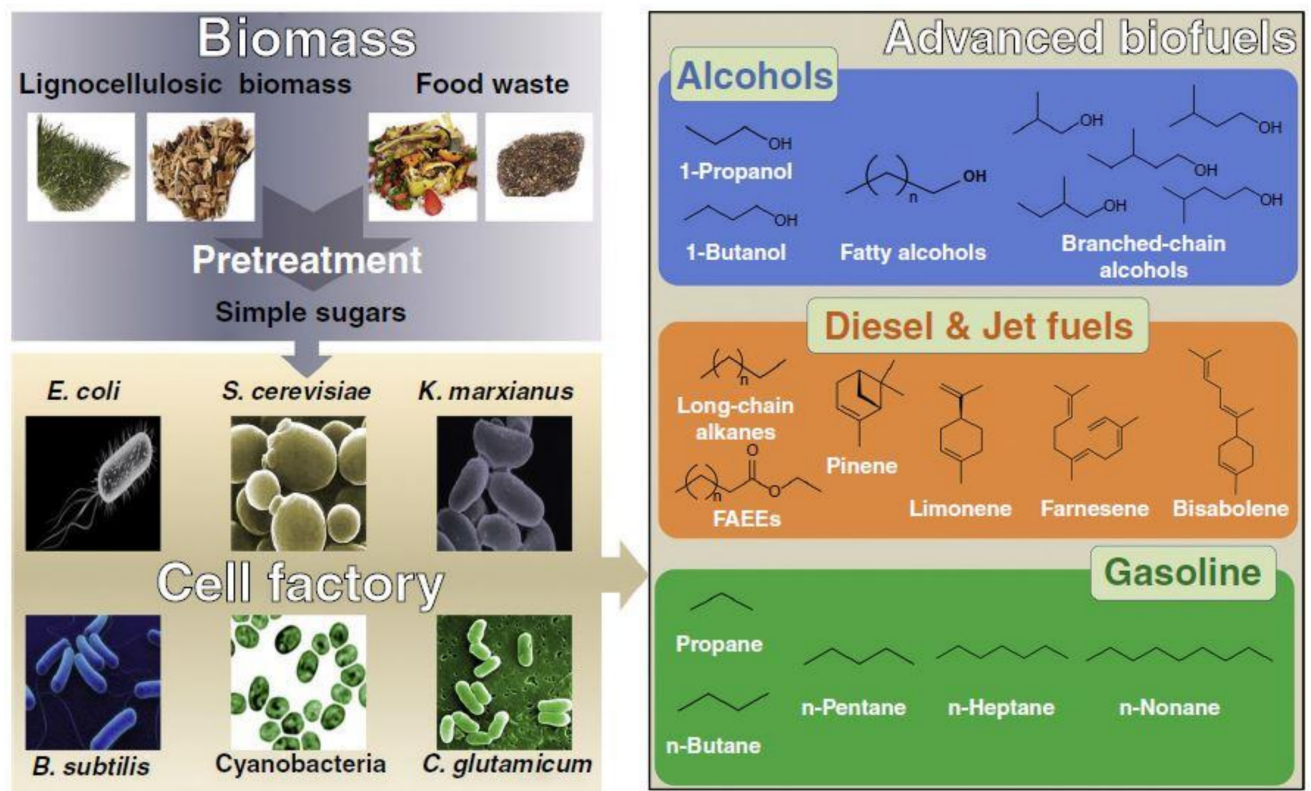

Figure 2. Advanced biofuels produced in engineered microorganisms from biomass. Reprint with permission [13]; 2016, Elsevier.

Careful attention to downstream conditions and final product use should be assessed during the design phase of a microorganism for the biofuels production pipeline: engine type (flicker or density ignition), energy content, combustion adeptness, ignition potential, cloud phase, volatility, grease, viscidness, chafing, smell, injuriousness, water miscibility, and expenditure [12]. The prime limitation to using microorganisms to convert biomass into cutting-edge biofuels is the lack of understanding of the endogenous metabolic pathways for biofuel generation at large-scale production. The introduction of exogenous biofuel pathways into productive hosts, such as E. coli and S. cerevisiae, has shown promise, but this technique has experienced challenges in handling recombinant enzyme expression and control with increased metabolic instability during the scaleup phase [14].

\section{Residue and Biomass}

Biomass residues may be classified into major, secondary, and tertiary ranks. Initial residues are usually yielded through the sowing of food harvests and forest products in the region, such as corn stalks and straw. Secondary residues are extracted when harvests are fully grown and treated in the final form of the product. Sugar cane bagasse, palm kernel cakes, and wood chips are sources of agriculture and dietary waste. Tertiary residues are obtainable after the consumption of a biomass-derived product by people and/or animals [15]. In fact, these waste streams exist in the form of municipal solid waste (MSW) and/or soluble organic fractions wastewater [15]. These sources of biomass and waste can be converted into bioenergy using engineered microorganisms to enhance the production quality of biofuels.

\section{Biochemical Pathways for Fuel Production}

\subsection{Pathways for Alcohol-Sourced Fuels}

Higher alcohol or short-chain chemicals can be used in gasoline as oxygenates or, in certain circumstances, as a complete gasoline replacement. For example, $n$-butanol, which contains $84 \%$ of the calorific value of gasoline, has a lower water solubility and is immiscible in water [16,17]. Wild-type microorganism strains, such as Clostridium acetobutylicum, were assayed for growth on different biomass sources, such as liquefied 
cornflour11, glycerol, glucose10 (a combination of treated biodiesel derived from fats) [18], and syngas (hydrogen and carbon monoxide mix). Even though C. acetobutylicum showed growth and butanol production, the rate of reaction is slow due to the strictly anaerobic reaction and solvent toxicity, making the butanol production no more than $13 \mathrm{~g} / \mathrm{L}$. Recently developed synthetic biology tools for the genetic manipulation of the Clostridium genus could potentially engineer strains that can overcome the slow reaction rates and diminish solvent toxicity [17].

\subsection{Pathways for Isoprenoid-Derived Fuels}

Isoprenoids are usually associated with pharmaceuticals and flavors [19], but isoprenoids have the capacity to function as energy-rich biofuels due to their ring and branch structure [14]. The short-chain alcohol, isopentanol, shows promise as gasoline fuel additives [14]. Even though branching decreases the cetane number (a measure of ignition efficacy in internal combustion engines), branching in straight-chain alkanes disrupts hydrophobic interactions and lowers the fuel freezing point [12]. The isoprenoid farnesene is synthesized in the industrial yeast strain S. cerevisiae PE-2 and is the closest to commercialization. This project was focused on developing a fully integrated and scalable process to produce farnesene from cellulosic sugars at USD 2 per liter in the U.S. It was reported that in 2019 , the project was $67 \%$ complete. The plant size could process 300,000 dry tons of pine wood per year (pulpwood quality). Bisabolane is another potential biofuel that is produced by a combination of microbial synthesis followed by chemical catalysis synthesis [12]. Biologically derived pinene dimerized using a green catalyst is a high-density fuel alternative with a net heat of combustion and density comparable to that of JP-10 jet fuel [20].

\subsection{Pathways for Fatty Acid-Derived Fuels}

Phosphoglycerates and triglycerides are the key components of cell membranes. They, along with fatty acids, oils, as well as other bioderived long-chain alkanes, are commonly used in biofuel production. The metabolism of fatty acid is well understood. Engineering microbes to produce nonnatural fatty acid-resultant chemicals have produced several candidates having the capacity to replace diesel [12].

\subsection{Pathways for Polyketide-Derived Fuels}

Natural product biosynthesis is performed by enzymes referred to as polyketide synthases (PKSs). Type 1 PKSs have been extensively studied due to their highly modular architecture. They have been heterologously expressed in host organisms to produce pharmaceuticals and other molecules of high value [21]. The repurposing of these PKS to produce defined high-value bioenergy molecules has faced many challenges. We still lack the understanding of how interactions between modular subunits affect the processivity and specificity of PKSs [22]. Recent advances in genomics, synthetic biology, and rational recombinant approaches will allow for the design and production of bioenergy molecules of interest.

Contamination may be a significant obstacle to effective activity if modern bioprocesses are extended [23,24]. For advanced biofuels to be widely accepted, they must compete with conventional fuels commercially, technologically, and environmentally. In addition, advanced biofuels need to address the price of feedstock economic and productivity constraints of scaling-up processes. Several advanced microbial biofuel candidates are facing scaleup challenges that prevent their entry to market [12]. Fatty alcohols compounds derived from plants or petrochemical sources are currently used in industry, having higher price rates than diesel. Such factors drove efforts to use metabolic engineering to create strains that generate these fatty alcohols. The use of microbes to convert biomass into these bioenergetic compounds has economical attraction, as they can control the chain length of the product, have tunable metabolic rates, and allow the use of nonplant oils as feedstocks. Hydrocarbon molecules of alkanes and alkenes have identically similar molecules to those 
of petroleum fuels on a chemical and structural basis. Thus, their use within existing transportation systems is not technically, or in practical terms, restricted [25].

\section{Types of Microorganisms: Wild Type vs. Engineered}

Broadly, microbes are categorized in two types, wild-type (WT) species and engineered, or genetically modified microorganisms (GMMs). WT microorganisms contain biochemical pathways as found in their native form but usually utilize a limited set of carbon sources and return yields that are much lower than what is commercially viable. Due to these constraints, there is much energy spent on the bioprospecting and screening of microorganisms to identify those with the potential to produce desired chemicals. Currently, optimization for high yields and carbon source selectivity to increase production are limited by the wild-type microorganism's metabolic potential [26,27].

The genetic engineering of microorganisms allows for the introduction of nonnative biochemical paths, the improvement of the overall metabolic functioning of the organism, and the selection of the desired final products. Effective treatment of the biosynthetic pathway genes and/or other regulated genes and pathways may allow organisms to offer a greater yield and selectivity to specific products [26]. Using synthetic biology, these GMMs can be further engineered to resist adverse growth environments, such as hydrolysate inhibitor resistance, thereby resulting in increased production yields [26].

GMMs have been extensively used in industrial chemical production due to being able to engineer them to tolerate biofuels' product toxicity [28] and to synthesize high-value chemicals using a wide range of carbon sources. The wide-ranging metabolic potential of GMMs and ample set of synthetic biology tools facilitate the introduction of heterologous pathways beyond the improvement of production titers and yields, as it can also be designed for the selection of desired biofuels [1]. Various GMM strains utilize certain biochemical routes to produce fuel-type molecules, which are briefly shown in Table 1.

Table 1. Various examples of microorganisms producing fuel-type molecules.

\begin{tabular}{ccccc}
\hline Microorganism & Class & Range & Concentration $(\mathbf{g} / \mathrm{L})$ & Reference \\
\hline E. coli BL21(DE3) (modified) & Alkanes & C13, C15, and C17 & 0.30 & {$[29]$} \\
C. acetobutylicum PJC4BK (GMM) & Mixed Oxygenates & acetone-butanol-ethanol & $25-33$ & {$[30]$} \\
C. acetobutylicum P260 (GMM) & Mixed Oxygenates & acetone-butanol-ethanol & $25-34$ & {$[30]$} \\
C. beijerinckii BA101 (GMM) & Mixed Oxygenates & acetone-butanol-ethanol & $25-35$ & $11.9-14.3$ \\
C. beijerinckii BA101 (GMM) & Oxygenates alcohol & butanol & $0.025-0.12$ & {$[30]$} \\
N. muscorum & Alkanes & n-C15-C18 & 0.006 & {$[30]$} \\
Rhodopseudomonas & Isoprenoids & n-C15-C20 & $0.8-2.25$ & 0.33 \\
D. desulfuricans & Alkanes & n-C11-C35 & {$[31]$} \\
Bacillus sp. & Mixed & C14-C34 & {$[31]$} \\
\hline
\end{tabular}

Examples of GMMs are E. coli strains, which provide different product concentrations. In E. coli BL21(DE3), the introduction of fatty acid reductase (FAR) from Synechococcus elongatus (PCC7942) and aldehyde deformylating oxygenase (ADO) from N. punctiforme (PCC73102) increased the overall production of aliphatic hydrocarbons of interest. Other modifications of E. coli BL21(DE3) inhibiting the transcription factor fadR are the aldehyde reductase (ALR) conversion of alkanes to fatty alcohols and acyl-coenzyme A (CoA) synthase/acyl-CoA dehydrogenase (FadD/E) degradation.

\section{GMM Risks and Regulations}

Microorganisms that have been genetically engineered offer a lot of potential for environmental applications. However, some may have unintended negative consequences. The fact that microbes are self-replicating entities makes it difficult to prevent an unfavorable effect simply by stopping additional discharges of the organism. One common complaint is that recombinant genes can be transmitted from their host bacterium to other bacteria once released into the environment. A review of horizontal gene transfer (through 
transformation, transduction, and conjugation) in various environmental conditions has been published [32]. Inter-specific horizontal gene transfer has been seen for many different bacteria, many genes, and in many distinct environmental conditions, according to the findings. It would be a mistake, therefore, to assume that recombinant genes put into the environment will not propagate to related bacteria unless additional measures are followed. Given the large number of bacteria that might be discharged, as well as their replication over a lengthy period of time, estimations of low, or nondetectable, DNA transfer in laboratory tests may be meaningless. On the other hand, a variety of methods have been developed to decrease horizontal gene transfer to other bacteria [33-35].

However, owing to energy inefficiency, to disruption of genomic coadaptation, or to domestication, it has been argued that genetically engineered microbes will be poor competitors and hence unable to survive in the wild. Many research studies have backed up the idea that genetically changed microbes are less fit than their progenitors; however, there are a few notable exceptions where genetic changes surprisingly improve competitive fitness. Furthermore, future evolution may remove certain genes' maladaptive effects, boosting the chances of a changed creature or its designed genes surviving. It is a difficult ecological and evolutionary challenge to assess the chance of a genetically modified microbe or its designed genes surviving.

As a result, an effective regulatory system would only need such assessments when probable possibilities for severe negative environmental impacts exist. The Cartagena Protocol on Biosafety, the Convention on Biological Diversity (CBD 2000) [36], and the International Plant Protection Convention (IPPC) [37], all of which address the environmental aspects of GMOs, should be followed when developing microbial biofuel production processes that include GMMs. Article 15 of the Cartagena Protocol on Biosafety requires a risk assessment to be conducted in accordance with scientific and transparent standards, using procedures that are previously known and accepted. The characterization process should take a multidisciplinary approach that (i) examines statistical methodologies, (ii) considers the individual components used to create the GMMs, and (iii) assesses the final result in its entirety (characteristics of the organism with new traits, information related to intended use, and an evaluation of the final result in its entirety). Furthermore, such projects must adhere to all hygienic regulations and guidelines established by municipal governments.

\section{Microbial Engineering for the Development of Innovative Biofuels and Biosynthetic Pathways}

Synthetic biology is opening doors to the fourth generation of biofuels. It introduces engineering principles, such as modularization and compartmentalization, to biological systems, leading to genetic circuitry systems design and control in microorganisms, with the aim of the development of a biological fuel manufacture platform as simple as configuring a computer [38]. Unlike high-value products, such as pharmaceuticals and enzymes, fuels are a commodity product with well-established production costs. The entry of biofuels into the general market can only be attained when the production costs are equal to or lower than those of drilling and refining petroleum.

In order to increase production and reduce costs of desired bioenergy molecules of interest, any nonessential cellular metabolic pathway that shunts the product through side reactions must be methodically assessed and controlled. In order to realize this aim, there needs to be a set of core host microorganisms with complementary synthetic biology technologies to enabling the speedy prototyping, testing, and optimizing of desired metabolic pathways. Currently, there are few microbial synthetic biology prototyping platforms optimized for the design, development, and deployment of GMMs in a predictable and dependable manner.

Microbial-produced advanced biofuel design starts from three central pathway metabolites: pyruvate, acetyl-CoA, and phosphoenolpyruvate. The building of a select metabolic pathway [39] can be accelerated by improved assembly methods instead of random evolutionary permutation selection. For instance, methods such as ligation-free assembly [40] and BioBricks [41] permit the prompt edifice of operons and paths from present DNA frag- 
ments or genetic factors. In addition, emerging in silico design tools promise to standardize rational biofoundry design to automate prototyping platforms [42].

\subsection{Engineered Metabolic Pathway to Produce Fuels from Isoprenoids}

Terpenes, also referred to as isoprenoids, are synthesized from 5-carbon isomeric compounds (C5), called isopentenyl pyrophosphates (IPP) or dimethylallyl pyrophosphates (DMAP). IPP and DMAP are derived from the mevalonate pathway (MEV) or the 1-deoxyd-xylulose 5-phosphate pathway (DXP), as shown in Figure 3 [43]. After biosynthesis of IPP or DMAP, it is possible to condense the 5-carbon compound through prenyltransferases to develop geranyl pyrophosphate, (GPP, C10), farnesyl-pyrophosphate (FPP, C15), and geranylgeranyl-pyrophosphate (GGPP, C20). Subsequently, the transformation of these prenyl pyrophosphates into monoterpenes (C10), sesquiterpenes (C15), and diterpenes (C20) occurs via terpene synthases [2].

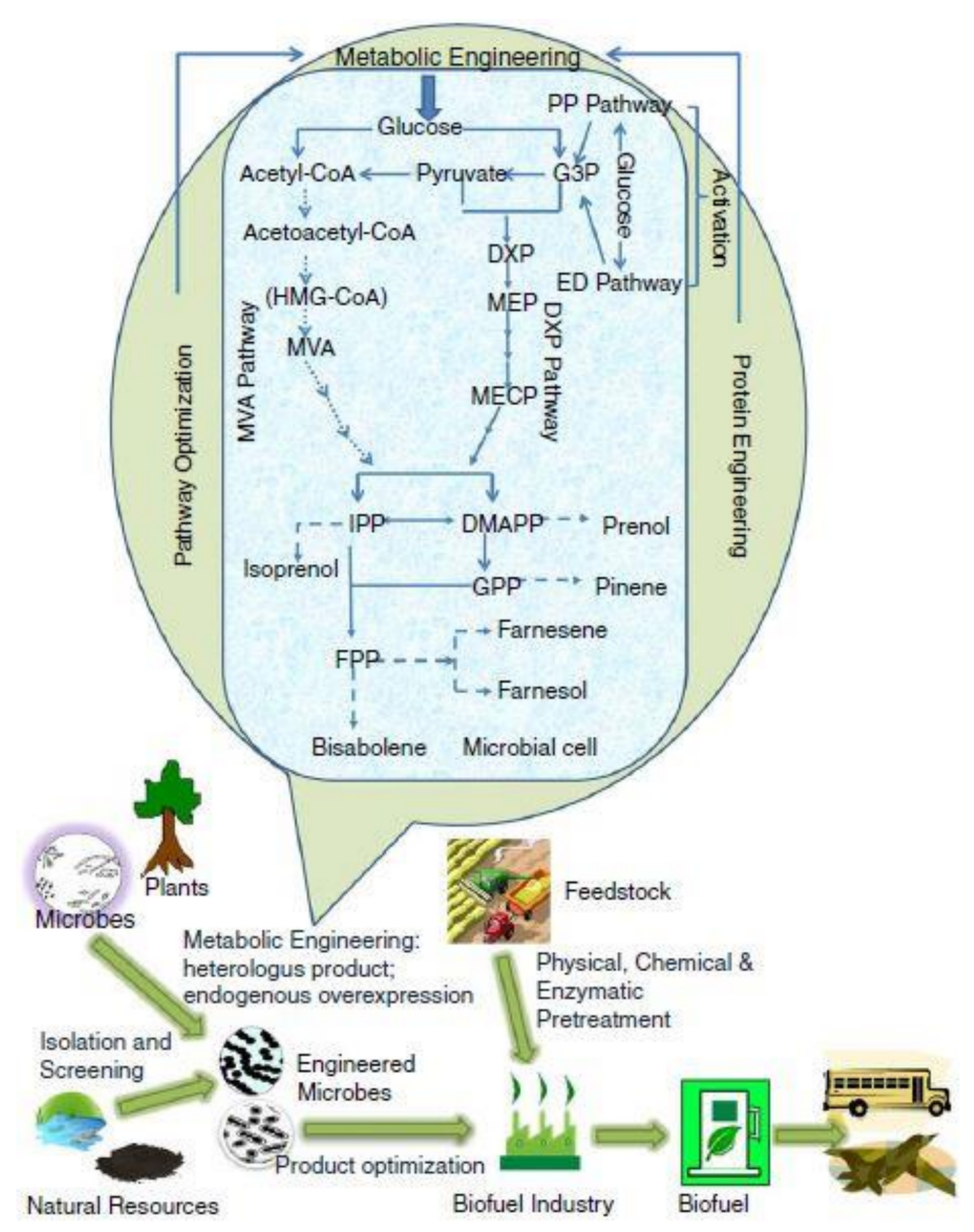

Figure 3. Isoprenoid-based fuel pathways. Reprint with permission [43]; 2015, Wiley.

Furthermore, the terpene biosynthetic pathway uses IPP, GPP, and FPP as substrates, hydrolyzing them via pyrophosphatases to generate drop-in fuel alcohols. Particularly, the products isopentanol and isoamyl acetate have been approved as fuel additives [44]. The identification and subsequent cloning of pyrophosphatase nudB from B. subtilis into E. coli was found to produce isopentanol through hydrolysis of IPP or DMAP [45]. FPP-derived farnesol and farnesene are highly desired drop-in diesel fuels precursors [2]. The production of farnesol in E. coli reached a concentration of $135 \mathrm{mg} / \mathrm{L}$ through the heterologous expression of the MEV pathway and over-expression of ispA (FPP synthase) [46].

Several companies have successful GMM platforms for the overexpression of isoprenoids employing MVA and DXP pathways. Effective MVA route engineering in both 
E. coli and S. cerevisiae indicated that its experimental efficiency and the redox balance of its enzymes are crucial elements in deciding the marketable feasibility of manufacturing larger molecules of higher energy density $[47,48]$. Recently, there has been a successful commercialization of farnesene production [47]. In addition, several authors have recently reported insights on using synthetic biology and engineered microorganisms and enzymes for the production of microbial fuels $[9,17,22,42,49]$.

\subsection{Engineered Metabolic Pathway to Produce Fuels from Fatty Acids}

The microbial synthesis of fatty acids (FAs) and their conversion into phospholipids is a well understood metabolic process [49]. The cultivating microorganisms in nutrient media with limited nitrogen, phosphorous, or sulfur has been used to switch from a growth phase to a FA synthesis and storage phase [49]. Despite the inability to utilize free FAs as drop-in fuels, their byproducts, such as fatty alcohols, fatty acid alkyl esters, fatty acid-derived alkanes, and alkenes, are high-value biofuel precursors for a number of reasons, such as low solubility in water, greater energy density, and reduced toxicity to the producing hosts $[50,51]$.

As shown in Figure 4, the FA biosynthesis route begins from acetyl-CoA, which is converted into malonyl-CoA and malonyl-ACP by acetyl-CoA carboxylase (ACC) and malonyl-CoA:ACP transacylase (FabD), respectively [13,51]. Fatty acyl elongation begins because of FabH catalysis that reduces malonyl ACP and acetyl-CoA to acetoacetyl ACP production. $\beta$-keto-acyl-ACP is then converted by FabG, FabZ, and FabI into acyl-ACP by a systematic series of $\beta$-keto-reduction, enoyl-reduction catalyses, and dehydration [52]. Through thioesterase-catalyzed hydrolysis, long-chain fatty acids are released from ACP. Acyl-ACP hydrolysis mitigates FAS inhibition feedback by acyl-ACP51, resulting in the effective FAS turnover and excess production of fatty acids.

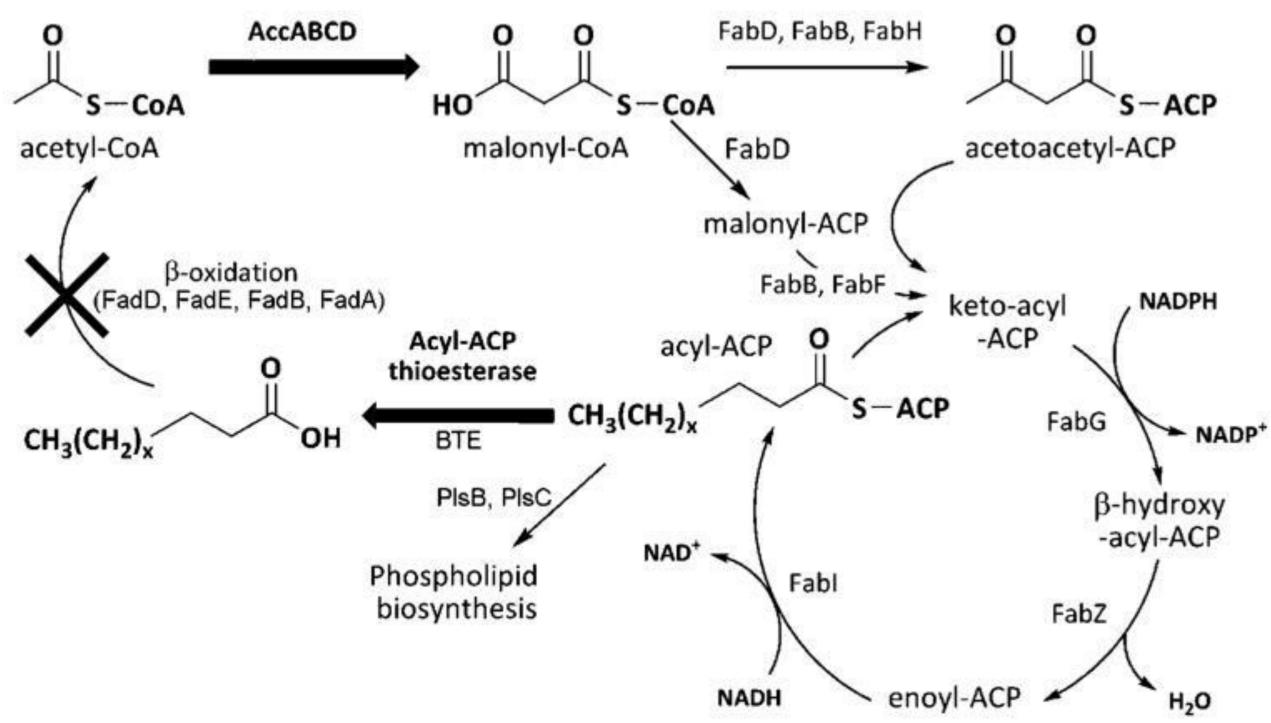

Figure 4. Fatty acid-based metabolic pathways. Reprint with permission [51]; 2010, Wiley.

Three approaches to metabolic engineering have been used to enhance free fatty acid yields. These are dynamic pathway regulations, organismal growth control, and pathway modification [53-57]. Using these processes, the heterologous expression of FA in E. coli reached $14 \%$ and $1.2 \mathrm{~g} / \mathrm{L}$ of fatty acids after a $72 \mathrm{~h}$ incubation period. Subsequent experiments eliminated the fadD gene that converts FAs into acid CoA while overexpressing ACC to maximize the amount of malonyl CoA produced by introducing plant thioesters from Umbellularia californica [52] and Cinnamomum camphorum [53]. This last strain had a FA yield efficacy of $4.5 \mathrm{~g} / \mathrm{L}$ with a $20 \%$ theoretical yield. The biosynthesis of FAs can be highly regulated with the production of $12-18$ carbon acyl chains $[58,59]$. 


\subsection{Engineered Metabolic Pathway to Produce Fuels from Alkanes}

Alkanes and alkenes are major components of diesel (C8-C21) [59]. A long-chain alkane biosynthetic route was formed by showing a three-gene FA producing pathway from Micrococcus luteus into E. coli [60]. Moreover, in E. coli, terminal alkenes were produced (mostly C18-C20) via the introduction of the cytochrome P450 OleTJE enzyme of Jeotgalicoccus spp., which helped decarboxylate alkene-free fatty acids [41]. As shown in Figure 5, the reduction of acyl-ACP (AAR) to aldehydes was further transformed into alkanes through an aldehyde decarboxylase (ADC) enzyme. When both genes were co-expressed in E. coli, a combination of alkanes (C13-C17) was formed, yielding $300 \mathrm{mg} / \mathrm{L}$ after a $40 \mathrm{~h}$ growth period [61]. Alkane biosynthesis genes have also been identified in cyanobacteria [62]. Cyanobacteria pathway expression in E. coli was one of the first methods adopted to enhance the large-scale synthesis of alkanes [63]. A high alkane yield was found after the FAR expression of Synechococcus elongatus PCC7942 and ADO expression of N. punctiforme PCC73102 along with a modified growth medium, which resulted in the production of a C13, C15, and C17 alkane mixture at $300 \mathrm{mg} / \mathrm{L}$ in the E. coli MG1655 strain [63,64].

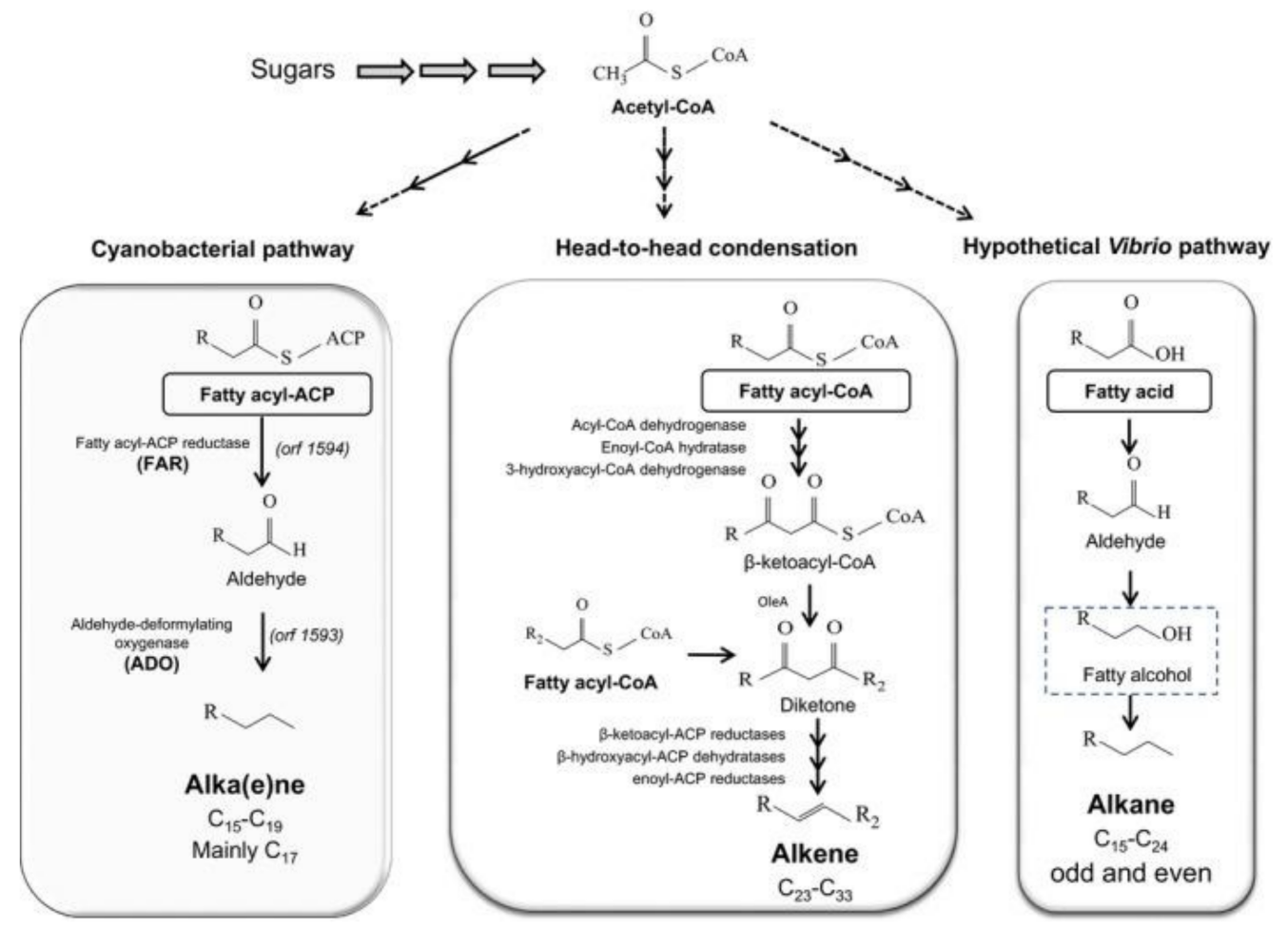

Figure 5. Schematic representation of the natural alkane biosynthesis pathways. Reprint with permission [63]; 2016, Wiley.

\subsection{Engineered Metabolic Pathway to Produce Fuels from Alcohol}

One of the first developed microbial higher alcohol production occurred in Clostridium strains exploiting the acetyl-CoA-dependent fermentation process [63]. Nevertheless, the difficulty in engineering Clostridium strains solely for producing butanol for use in acetonebutanol-ethanol (ABE) mixtures, as well as its slow growth rate, has made it incompatible for alcohol production on a commercial scale $[64,65]$. Since then, a significant amount of research has been published using E. coli and S. cerevisiae to produce various branches and linear chain alcohols.

Several optimization schemes have been employed using two metabolic routes, as shown in Figure 6: ABE pathway, using acetyl-CoA as a precursor, and keto-acid pathway, starting from amino acid biosynthesis [47]. There is strong interest in commercializing $n$-butanol and isobutanol as they can be used as drop-in fuel additives. A published study revealed that the theoretical production of isobutanol was increased by engineering the 
last step of the isobutanol production pathway in E. coli $[66,67]$, in which NADH was the cofactor. Another study showed that the accumulation of NADH drove the n-butanol yield up to $30 \mathrm{~g} / \mathrm{L}$ due to the NAD/NADH imbalance in the cellular system [68].

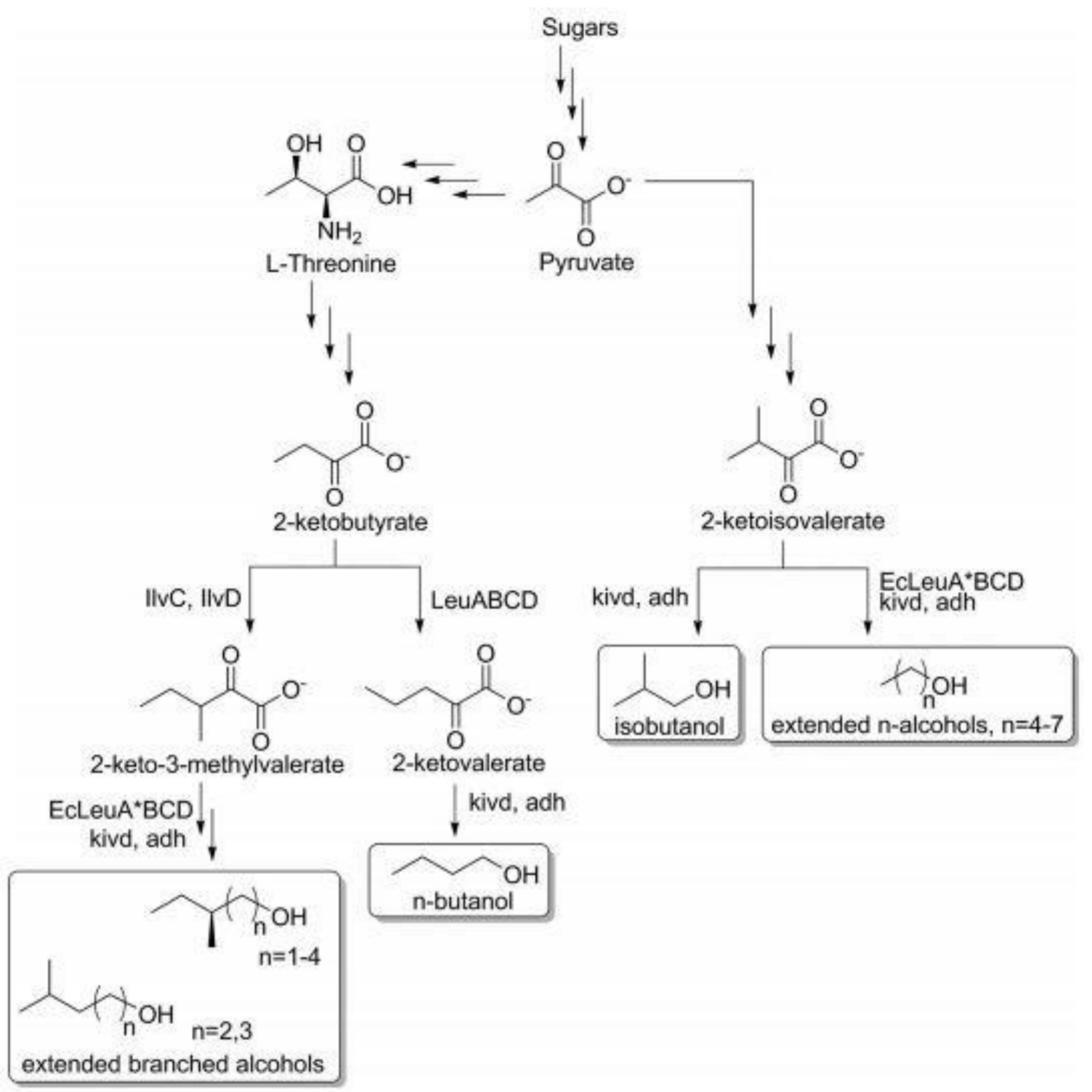

Figure 6. Higher-alcohol-producing pathway. Reprint with permission [47]; 2018, Wiley.

In S. cerevisiae, the deletion of two alcohol dehydrogenases (ADH1 and ADH4) and the heterologous expression of the cytosolic pyruvate dehydrogenase (cytPDH) was shown to prevent the formation of ethanol, and glycerol had an enhanced u-butanol production $(12 \mathrm{~g} / \mathrm{L})$ [69]. Meanwhile, the deletion of ADH1 in a separate S. cerevisiae strain led to higher $\mathrm{u}$-butanol production $(24.28 \mathrm{~g} / \mathrm{L})$ of the keto-acid pathway by the catalysis of threonine and subsequent conversion to a 2-ketoacid precursor [70].

\subsection{Sugar Synthesis from $\mathrm{CO}_{2}$ by Microorganisms to Produce Bioenergy Carrying Molecules}

The ability to fix atmospheric $\mathrm{CO}_{2}$ into sugars for biomass production provides the opportunity to close the loop in fossil fuels emissions. The incorporation of $\mathrm{CO}_{2}$ into biofuel provides a possible solution for minimizing carbon pollution and the use of fossil fuels. The biochemical entrance to the organic biosphere is carbon fixation through autotrophs, as shown in Figure 7, in which microbes may use light, hydrogen, or sulfur to absorb $\mathrm{CO}_{2}$ into organic composites at ambient temperature and pressure [71]. 


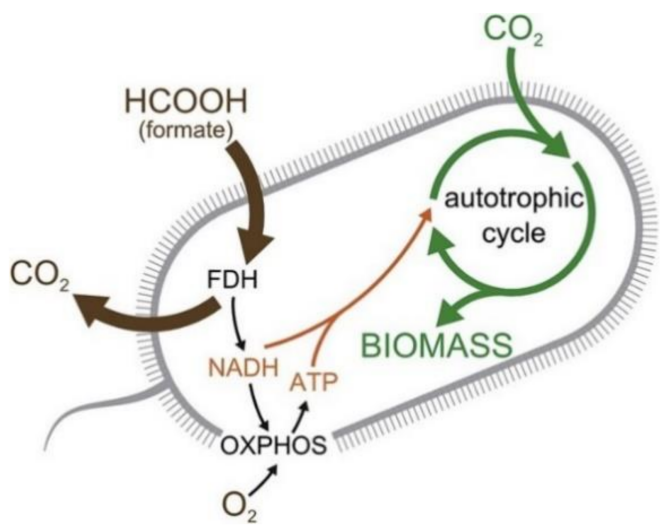

Figure 7. Schematic representation of the engineered synthetic chemo-autotrophic E. coli. Reprint with permission [71]; 2019, Elsevier.

Several natural $\mathrm{CO}_{2}$ fixation pathways have been reported [72]. The Calvin-BensonBassam (CBB) cycle is the major environmental carbon assimilation atmospheric $\mathrm{CO}_{2}$ to-biomass pathway, as shown in Figure 8 [73]. The photosynthetic assimilation of $\mathrm{CO}_{2}$ (not discussed in this review) accounts for a large fraction of the process. Unfortunately, current synthetic biology tools lack genetic manipulation protocols of photosynthetic model organisms, such as algae.

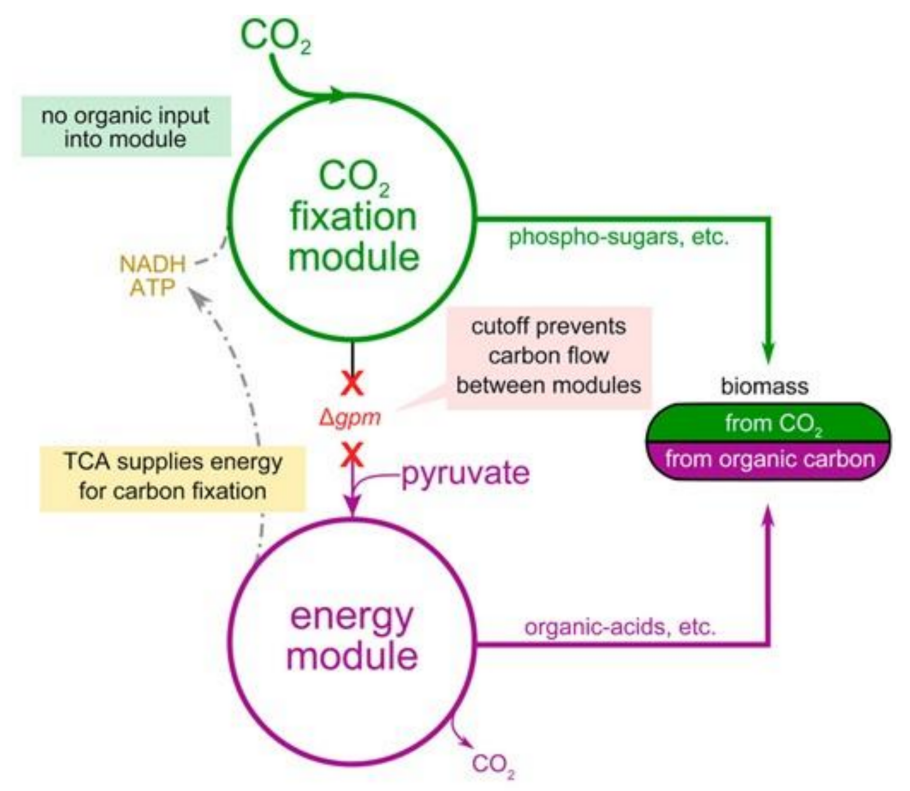

Figure 8. Calvin-Benson-Bassam cycle for carbon fixation. Reprint with permission [73]; 2016, Elsevier.

Antonovsky et al. [73] showed that the biosynthesis of sugars from $\mathrm{CO}_{2}$ occurs in the CBB cycle in twelve reactions. Two key enzymes are absent in E. coli, namely ribulose1,5-bisphosphate carboxylase (Rubisco) and phosphoribulokinase (PRK). The insertion of Rubisco and PRK genes along with the native gluconeogenesis and pentose phosphate pathways provide E. coli with the enzymatic mechanism to carry out CBB cycle reactions, resulting in the synthesis of sugar and other biomass compounds directly from $\mathrm{CO}_{2}$ fixation [73].

$\mathrm{CO}_{2}$ fixation via Calvin-cycle enzymes was reported to improve ethanol yields in yeast [74]. Glycerol output represents $4-10 \%$ of overall sugar consumption in anaerobic yeast colonies, and thus, has major impacts on both first- and second-generation large-scale bioethanol processing. The conversion of carbon dioxide into higher alcohols through integrated electro-microbial conversion processes has also been investigated $[75,76]$. Elec- 
tromicrobial processes are one of the few technologies utilized to fix $\mathrm{CO}_{2}$ using autotrophic microbes [71].

\section{Pretreatment Processes}

\subsection{Pretreatment of Lignocellulosic Biomass}

Lignocellulose feedstock is composed of waste products, such as agricultural residues, kitchen organic waste, production waste, and wood waste, which are promising sources of organics and carbohydrates for biofuels production as they do not compete with food biomass [66]. Lignocellulosic biomass comprises about 50\% of the world's biomass, and its annual production was estimated as 180 billion tons [77]. Biomass composition ranges from 40 to $50 \%$ cellulose-a glucose polymer, 25 to $35 \%$ hemicellulose-a sugar heteropolymer, and 15 to 20\% lignin-a phenyl-propane entity that cannot be fermented, as well as minimal portions of mineral deposits, fats, solvable polysaccharides, and additional constituents [78]. Biofuel production from lignocellulose comprises the pretreatment of the biomass, polysaccharides enzymatic hydrolysis to monomeric sugars, and fermentation into alcohol, as shown in Figure 9. Lignin can be retrieved and employed in the form of fuel used for heat and electricity during ethanol production [79].
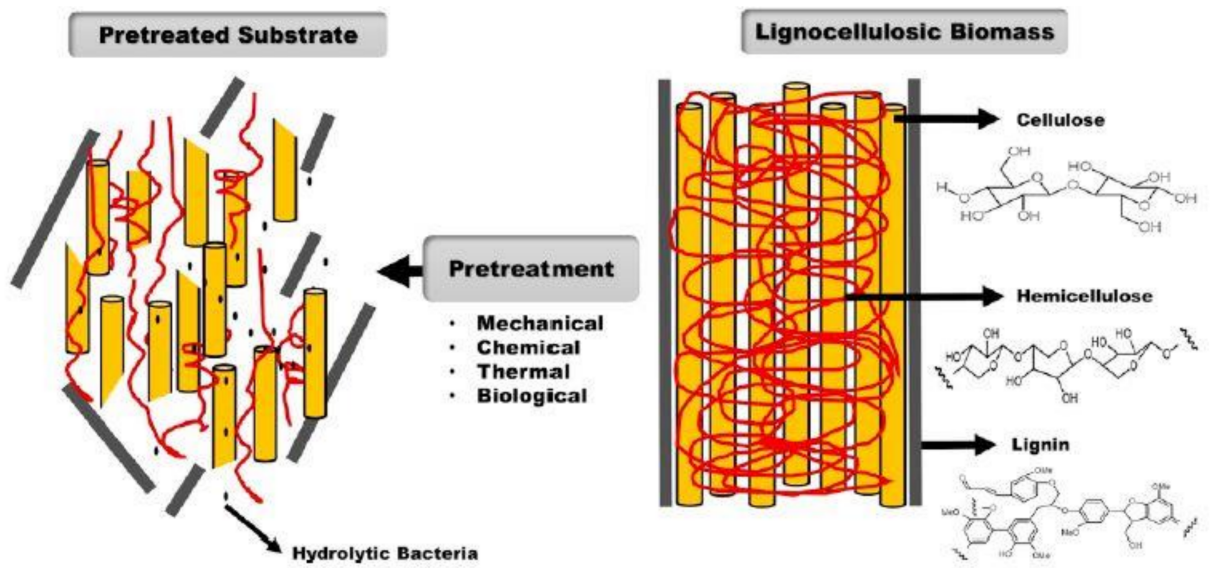

Figure 9. Schematic of lignocellulosic biomass pretreatment. Reprint with permission from [79]; 2019, Elsevier.

\subsection{Biological Pretreatment of Lignocellulosic Biomass}

Pretreatment processes need to satisfy the following conditions in order to optimize for biofuels production [79,80]: avoiding damage to the hemicelluloses and cellulose, producing far less residues, preventing the creation of any inhibitors of fermenting microorganisms and hydrolytic enzymes, reducing the energy consumption, decreasing the feedstock size and cost, and reducing the dependency on chemicals. Currently, several pretreatment processes are being used in industry. They are categorized as chemical, physical, and physicochemical, according to the energy applied during the pretreatment process [81].

Chemical and physical methods are energy-intensive, incur a high cost, use nongreen solvents, and can produce inhibitors of downstream biological processes. In biological pretreatment, biomass is directly converted to desirable products, inhibitor production is minimized, chemical additives are not required, and it requires low-energy consumption. Therefore, this method is regarded as a sustainable environmentally friendly process [81,82]. This technology utilizes microorganisms, such as white and soft-rot fungi, bacterial organisms, and actinomycetes, which can decompose the recalcitrant compounds in feedstocks (lignin) [81,83].

Enzymatic pretreatment results in the partial or complete degradation of lignin from lignocellulosic structures [84], resulting in improved biomethane production through anaerobic fungal, enzymatic, or microbial digestion [85]. Wet oxidation pretreatment processes were the most efficient of all tested processes and specifically increased the efficiency of 
anaerobic digestion, while producing less fermentation inhibitors [86]. Biological pretreatments provide microbes with accessibility to fractions of cellulosic biomass for enhanced hydrolysis and result in less carbohydrate loss. Solid-state biological pretreatment using white-rot fungi has many advantages over other pretreatment processes as it can be applied to a wide range of biomass substrates. Unfortunately, solid-state biological pretreatment takes a long time to occur and requires more space than other biological treatment processes [80]. The optimal pretreatment of lignocellulosic pretreatment for downstream processes highly depends on both the type of biomass and the pretreatment process selected [80-88].

\subsection{Enzymatic Pretreatment}

Hemicellulose and cellulose hydrolyzation is regarded as the slowest step of a metabolic pathway through the process of anaerobic digestion [89]. Therefore, during the hydrolyzation process, endogenous enzymes are required to accelerate the anaerobic digestion of cellulosic biomass. Biomass, such as pulp and paper sludge, pre-treated with an extract of mushroom compost extract that has a rich quantity of carboxymethyl cellulase and laccase (lac) hydrolyzation, promoted the production of methane by $34.2 \%$ compared to the untreated control [90], wherein pre-treated hydrolysates of spent hops and sugar beet pulp helped to diminish organic content matter about $7 \%$ and $23 \%$, respectively, resulting in an enhancement of methanation by 13-19\% [91].

\subsection{Fungal Pretreatment}

The conversion of lignocellulose to biofuel using fungal pretreatment is highly dependent on the lignin and hemicellulose degradation. White-rot fungi have been found to be the most efficient pretreatment fungus for the generation of biogas derived from lignocellulosic biomass [92]; still, pretreatment using the fungal method necessitates a sterilization process of the lignocellulosic feedstock. At a ratio of 1:2 of Chestnut leaves and hay pretreated at $37^{\circ} \mathrm{C}$ and for 2-3 weeks, a wood-decomposing fungus intensified bio-gasification by $15 \%$, compared with untreated biomass [93]. The main factor for the enhancement of lignocellulosic biomass degradation by white-rot fungi, regardless of the presence of lignin-degrading enzymes, is the ability to yield xylanases, cellulases, and hemicellulases [84,94]. Though almost all fungi excrete lac, as well as manganese peroxidase $(\mathrm{MnP})$, a select set of fungi can also secrete lignin peroxidase $(\mathrm{LiP})$ through the pretreatment process with lignocellulosic biomass [80]. The length of time required for fungal lignocellulosic biomass pretreatment makes this process less than optimal [95-97]. Treating the biomass with a combination of fungal pretreatment and different methods, such as acid or base pretreatment, has demonstrated a considerable increase in lignocellulosic biomass degradation $[98,99]$.

\subsection{Bacterial Pretreatment}

The use of bacteria, such as Novosphingobium sp. B-7 and Cupriavidus basilensis B-8, has been shown to degrade lignin; however, the application of bacteria as a lignocellulosic pretreatment is still rare due to the incomplete understanding of the mechanism of biomass pretreatment using bacteria [100-102]. The bacterial degradation of lignocellulosic biomass is due to two processes: the degradation of extracellular lignin and the degradation of intracellular aromatic components derived from lignin [103].

Extracellular bacteria peroxidases, such as lac and $\mathrm{MnP}$, have been shown to have high catalytic efficiency toward the degradation of lignin [102]. Several species of cellulolytic bacteria have been studied to elucidate their mechanism of action [84]. For example, Cellulomonas fimi, Thermomonospora fusca, and Paenibacillus campinasensis are of interest as they can live in inhospitable environments [104]. More than 30 cellulolytic bacteria, such as F. succinogenes and R. albus, isolated from bovine rumen bind to cellulose and initiate the hydrolyzation of cellulose [105]. 
Zymomonas mobilis, an anaerobic bacterial species, has been found to be a cellulolytic type, which is utilized for fermenting sucrose, glucose, and fructose for providing a high ethanol yield [106-108]. Lignin degradation has been investigated traditionally using fungal pretreatment. Recent renewed interest has pushed for research into bacteria-driven lignin degradation [81,109]. Azospirillum lipoferum and Bacillus subtilis are two bacteria of interest due to the fact that they can produce lac and, thus, can degrade lignin [109]. In addition, bacterial strains with peroxidases, lac, and $\beta$-etherases were shown to degrade lignin [110-112].

\subsection{Pretreatment of the Organic Fraction of Municipal Solid Waste}

The organic fraction of municipal solid waste (OFMSW) consists of a complex mixture of polysaccharides, proteins, and fats that require pretreatment due to the presence of lignocellulosic biomass in OFMSW [113]. Thus, pretreatment prior to anaerobic digestion is necessary to (A) transform the large molecules into simpler molecules, (B) offer a larger surface area for degradation, and (C) promote the accessibility of food for microorganisms by increasing the substrate porosity [114]. Several methods of pre-treatment that have been studied are classified as physical pretreatment [115], chemical pretreatment [116], thermal pretreatment [117], biological pretreatment [118], and combinational pretreatment [119].

\subsection{Biological Pretreatment to Produce Biofuels from OFMSW}

Fungi strains, such as white-rot basidiomycetes Phanerochaete chrysosporium, and Pleurotus ostreatus, can degrade lignin via the activity of enzymes LiP, MnP, and lac [119]. Lignin is completely degraded during fungal pretreatment due to enzymatic activity, while avoiding the production of phenolic compounds, unlike traditional chemical methods. Microorganisms could play a role in the consumption of glucose, providing reducing equivalents to meet the requirement of their energy and degradation of phenol by excreted fungal enzymes [119]. Although P. chrysosporium and P. ostreatus have been utilized to degrade lignocellulosic biomass, the use of these systems for the pretreatment of OFMSW is not presented in the literature [113], but another fungus, Aspergillus awamori, was studied as a pretreatment for OFMSW [120]. The major issue facing the enzymatic hydrolyzation of OFMSW is the heterogeneous and inconsistent nature of its composition. Thus, the utilization of enzyme cocktails that degrade large complex molecules, such as carbohydrates, lipids, and proteins, are required. This degradation results in simpler molecules, such as fatty acids and sugars, that are used as a source of nutrients by microbes [120,121].

\subsection{Biological Pretreatment of Wastewater}

Farming wastewater solid biomass is composed of lignin (10-25\%), cellulose (35-50\%), and hemicellulose (20-35\%) [122]. Hemicellulose and cellulose are linked to lignin via covalent and hydrogen bonds, rendering it resistant to degradation [123]. The pretreatment of farming wastewater prior to hydrolysis could considerably improve the hydrolysis efficacy by removing hemicellulose and lignin, reducing the crystallinity of cellulose, and increasing waste solids porosity [80]. Enzymatic hydrolysis was conducted via cellulase enzymes, with fermentation being performed by microbes (e.g., bacteria and yeast) [124].

Agricultural wastewater could be treated using enzymes or lignin-degrading microorganisms (e.g., white-, soft-, and brown-rot fungi) [125]. Brown-rot fungi can be used on soft wood biomass prior to fermentation [126]. Soft-rot and white-rot fungi preferentially degrade cellulose, hemicellulose, and lignin constituents of farming waste and improve the enzymatic hydrolysis of agricultural waste. Additionally, basidiomycetes, for example, Phanerochaete chrysosporium, have been found to degrade farm waste [81,127]. The pretreatment of agricultural pulp waste employed Streptomyces and white-rot fungi for the degradation of lignin where lignin reduction was measured in hard wood $(23.5 \%)$ and soft wood (10.5\%) [128]. Delignification (85.6\%) was attained in sawdust by a $55.2 \mathrm{~g} / \mathrm{L}$ pretreatment with a cellulose enzyme (derivative of Trichoderma/Hypocrea) [128]. Moreover, rice straw was biologically pre-treated with a white-rot fungus, Pleurotusostreatus, for 44 days 
for the purpose of lignin removal: this pretreatment degraded cellulose $(24.30 \%)$ and lignin $(27.85 \%)$ within 24 days [129]. The leading drawback of these processes was the length of pretreatment due to a lower hydrolysis rate by fungi. This made the process economically unfeasible at a commercial scale [130]. The summary of different pretreatment methods is shown in Table 2.

Table 2. Pretreatment methods and results example.

\begin{tabular}{|c|c|c|c|c|}
\hline $\begin{array}{l}\text { Pretreatment } \\
\text { Method }\end{array}$ & Considerations & Pretreatment Conditions & Results & Ref \\
\hline Physical & $\begin{array}{l}\text { Physical pretreatment techniques have been shown } \\
\text { to increase the available surface area and pore size } \\
\text { necessary for successful enzymatic reactions. The } \\
\text { majority of the techniques used, however, are } \\
\text { unable to remove the lignin. Before applying } \\
\text { thermal or chemical pretreatments, physical } \\
\text { techniques are usually employed as a step. }\end{array}$ & $\begin{array}{l}\text { Feedstock: Cellulose, } \\
\text { hemicellulose. Conditions: } \\
\text { Mechanical pulverization, } \\
\text { particle sizes of } 33 \text { to } 6 \mathrm{~mm}\end{array}$ & $\begin{array}{c}\text { Increased methane yield } 11-13 \% \\
\text { Energy cost is high; particle } \\
\text { diameter should be } 6 \mathrm{~mm} \text { for } \\
\text { high methane yield }\end{array}$ & [131] \\
\hline Chemical & $\begin{array}{l}\text { Chemical techniques have shown to be highly } \\
\text { efficient in expanding the available surface area of } \\
\text { lignocellulosic biomass, as well as providing } \\
\text { partial-to-complete delignification. It is also } \\
\text { possible to obtain a considerable reduction in } \\
\text { cellulose crystallinity, as well as partial-to-total } \\
\text { hemicellulose solubilization. Pretreatment using } \\
\text { chemicals is usually linked with the greatest } \\
\text { pretreatment rate. The most significant drawback of } \\
\text { chemical pretreatment techniques is the significant } \\
\text { chemical consumption linked with high costs and } \\
\text { environmental issues. }\end{array}$ & $\begin{array}{c}\text { Feedstock: Rice straw } \\
\text { Conditions: } 0.25 \text { and } 0.5 \mathrm{M} \\
\text { of sodium carbonate at } 90, \\
110 \text {, and } 130^{\circ} \mathrm{C} \text { and for } 1, \\
2 \text {, and } 3 \mathrm{~h}\end{array}$ & $\begin{array}{l}\text { The rice straw pretreated with } \\
0.5 \mathrm{M} \text { of sodium carbonate at } \\
110^{\circ} \mathrm{C} \text { for } 2 \mathrm{~h} \text { demonstrated the } \\
\text { highest improvement among the } \\
\text { pretreatments, resulting in the } \\
\text { production of } 292 \mathrm{~mL} / \mathrm{g} \text { of } \\
\text { methane }(125 \% \text { improvement } \\
\text { compared with the } \\
\text { untreated straw). }\end{array}$ & [132] \\
\hline Thermal & $\begin{array}{l}\text { Previous study has shown that heat pretreatment } \\
\text { can reduce cellulose crystallinity, lower the degree } \\
\text { of polymerization, and solubilize lignin. When } \\
\text { combined with high pressure, the impact of } \\
\text { temperature has been observed to be superior. The } \\
\text { thermal method's high energy-de-manding nature } \\
\text { is the primary impediment to its industrial use. The } \\
\text { combined thermos-chemical pretreatment has } \\
\text { proven to be a viable alternative to just thermal and } \\
\text { chemical pretreatments, combining the benefits of } \\
\text { both procedures while reducing chemical and } \\
\text { energy usage. }\end{array}$ & $\begin{array}{l}\text { Feedstock: Wheat } \\
\text { straw / corn stover } \\
\text { (mixed)Conditions: } \\
\text { Soaking } 0.2 \% \mathrm{H}_{2} \mathrm{SO}_{4} \text {, } \\
\quad 190^{\circ} \mathrm{C}, 5 \mathrm{~min} .\end{array}$ & $\begin{array}{c}>50 \mathrm{~g} \mathrm{~L}^{-1} \text { Ethanol }>50 \mathrm{~g} / \mathrm{L} \\
\text { Overall yield } 74-78 \%\end{array}$ & [133] \\
\hline Biological & $\begin{array}{l}\text { Biological techniques have proven to be highly } \\
\text { effective in decreasing the degree of cellulose } \\
\text { polymerization, hydrolyzing hemicellulose, and } \\
\text { delignification. The advantages of this approach } \\
\text { over other pretreatment methods include a minimal } \\
\text { chemical need and low energy usage. They are } \\
\text { recognized for being the most eco-friendly } \\
\text { pretreatment method. Biological techniques, on the } \\
\text { other hand, are typically limited in their } \\
\text { commercial use due to their poor hydrolysis rate } \\
\text { and high cost (when specific enzymes are used). }\end{array}$ & $\begin{array}{l}\text { Feedstock: Wheat straw } \\
\text { Microorganism/Enzyme: } \\
\text { Ceriporiopsis } \\
\text { subvermispora } \\
\text { Conditions: } 7 \text { weeks of } \\
\text { solid-state fermentation } \\
\text { incubated at } 24^{\circ} \mathrm{C} \text {. }\end{array}$ & $\begin{array}{l}\text { In vitro gas production of } \\
297 \mathrm{~mL} / \mathrm{g} .\end{array}$ & [134] \\
\hline
\end{tabular}


Table 2. Cont.

\begin{tabular}{|c|c|c|c|c|}
\hline $\begin{array}{l}\text { Pretreatment } \\
\text { Method }\end{array}$ & Considerations & Pretreatment Conditions & Results & Ref \\
\hline Enzymatic & $\begin{array}{l}\text { Recent research has focused more emphasis on the } \\
\text { enzymatic pretreatment approach because of the } \\
\text { potential it offers for increasing biofuel production, } \\
\text { particularly biomethane synthesis. The enzymatic } \\
\text { pretreatment of lignocellulosic biomass employs } \\
\text { oxidative and hydrolytic enzymes generated mostly } \\
\text { by bacteria and fungi. This pre-treatment approach } \\
\text { is gaining popularity because of the quick reaction } \\
\text { time, low nutrient requirements for enzymatic } \\
\text { reactions, and the fact that most enzymes are } \\
\text { unaffected by inhibitors and other microbial } \\
\text { metabolisms. Furthermore, the enzymatic } \\
\text { pretreatment does not necessitate the use of costly } \\
\text { processing equipment. However, the high cost of } \\
\text { enzymes continues to be a barrier to the economic } \\
\text { viability of this pretreatment approach for } \\
\text { increased fuel generation on a large scale. }\end{array}$ & $\begin{array}{c}\text { Feedstock: Agricultural } \\
\text { residue; sugar beet pulp, } \\
\text { spent hops, manure, } \\
\text { biofiber, MSW, paper pulp, } \\
\text { wheat grass. } \\
\text { Microorganism/Enzyme: } \\
\text { Laccase, mixture of } \\
\text { cellulases, hemicellulases } \\
\text { and } \beta \text {-glucosidase, } \\
\text { pectinase, Trichoderma } \\
\text { enzyme complex } \\
\text { Conditions: } 37^{\circ} \mathrm{C} \text { for } \\
\text { 4-24 h. Autoclave. } \\
\text { Aerobic/anaerobic }\end{array}$ & $\begin{array}{l}0-34 \% \text { improved } \\
\text { methane production }\end{array}$ & [85] \\
\hline Fungal & $\begin{array}{l}\text { Fungal pretreatment utilizing lignin-degrading } \\
\text { microorganisms, such as preliminary white-rot } \\
\text { fungi, has resurfaced as a viable option to } \\
\text { thermal/chemical pretreatment for cellulosic } \\
\text { ethanol production, both economically and } \\
\text { environmentally. It has been demonstrated that } \\
\text { fungal pretreatment may improve the enzymatic } \\
\text { digestibility of a variety of biomass feedstocks, } \\
\text { including maize stover, wheat straw, rice straw, } \\
\text { cotton stalks, and woody biomass. Simple } \\
\text { procedures, minimal energy needs, decreased waste } \\
\text { streams, lower downstream processing costs, and } \\
\text { reduced inhibitors to ethanol fermentation are all } \\
\text { advantages of this approach over thermochemical } \\
\text { pretreatments. Despite the benefits, the main } \\
\text { drawbacks of fungal pretreatment include } \\
\text { significant cellulose and hemicellulose loss and a } \\
\text { protracted pretreatment period. }\end{array}$ & $\begin{array}{l}\text { Feedstock: Agricultural } \\
\text { residue; chestnut leaves } \\
\text { and sisal leaves } \\
\text { Microorganism/Enzyme: } \\
\text { Fungi (white, brown, and } \\
\text { soft rot) and } \\
\text { Basidiomycetes } \\
\text { Conditions: } 28-37^{\circ} \mathrm{C} \text { for } \\
12 \text { days to } 8 \text { weeks. } \\
\text { Autoclave/no } \\
\text { autoclave. Aerobic }\end{array}$ & $\begin{array}{c}15 \% \text { to fivefold } \\
\text { increased methanation }\end{array}$ & [85] \\
\hline Bacterial & $\begin{array}{l}\text { Bacterial pretreatment is a screening and } \\
\text { application method that uses microorganisms } \\
\text { isolated from the natural environment to aid in the } \\
\text { hydrolysis of biomass during anaerobic digestion. } \\
\text { Bacterial consortia used in pretreatment should } \\
\text { obviously have the ability to degrade cellulose and } \\
\text { hemicellulose. In anaerobic digestion of distillery } \\
\text { wastewater-fortified cassava waste, a bacterial } \\
\text { community isolated from a thermophilic } \\
\text { straw-decomposing landfill exhibited a } 96 \% \text { greater } \\
\text { methanation at } 55^{\circ} \mathrm{C} \text { than its untreated equivalent. }\end{array}$ & $\begin{array}{l}\text { Feedstock: Agricultural } \\
\text { residue; corn straw, corn } \\
\text { stalk, cassava residue, and } \\
\text { cotton stalk. } \\
\text { Microorganism/Enzyme: } \\
\text { Complex mixture } \\
\text { containing yeast and } \\
\text { cellulolytic bacteria, } \\
\text { heat-treated sludge, } \\
\text { Clostridium } \\
\text { thermocellum, mixture of } \\
\text { fungi and } \\
\text { compost-forming } \\
\text { microorganism. } \\
\text { Conditions: } 20-55^{\circ} \mathrm{C} \text { for } \\
12 \text { h to } 20 \text { days. } \\
\text { Autoclave } / \text { no } \\
\text { autoclave. Aerobic }\end{array}$ & $\begin{array}{l}25-96.63 \% \text { enhanced } \\
\text { methane production }\end{array}$ & [85] \\
\hline
\end{tabular}

\section{Outlook and Possibilities}

\subsection{Application of Microbial Fuels in Transport, Aviation, and Shipping}

For years, liquid fuels have been the primary energy source for all IC engines used in various means of transportation such as road, air, marine, and rail. Fossil-based hydrocarbon fuels are commonly used in present-day infrastructures but have been associated with the emission of noxious gases and PM due to incomplete combustion as a result of the absence of oxygen in the fuel and insufficient oxidative oxygen, leading to environmental pollution and greenhouse effects. Electric vehicles have been adjudged as one of 
the solutions of zero-carbon means of transportation. While the use of electric vehicles seems to be an ideal solution for short-haul travel, battery-electric vehicles will probably not be a feasible solution for long-distance travels and heavy-duty machinery such as tractor trailers, cargo ships, and passenger jets, because power storage options are bulky and heavy, thus affecting overall transport efficiency. Microbial biofuels could be a cheaper and better alternative. Notably, microbial biofuels can be drawn from nonedible plants biomass, municipal and sewage wastes, and microorganisms themselves; thus, the sustainability and economic viability of biofuels will become commercially viable with further advances in biofuel production technologies. Studies have shown that physicochemical properties can have significant effects on clean and efficient biofuels. These properties are therefore necessary for the design of IC engines and accessories that control fuel injection, spray/atomization characteristics, and the combustion regime. Biofuels' molecular structures and functionality have been identified as having significant effects on their applications, leading to technical incompatibility with the existing fuel infrastructure [135]. With fuel design concepts, microbial biofuels can be restructured, refunctionalized, and tailored to emulate the composition of real fuel, thereby cutting down the effects of structural differences in biofuels and exacting better performance in IC engines. Integrating biofuel and engine design and co-optimizing the design and operation processes can further enhance the application and utilization of biofuels in our transport, aviation, and shipping sectors.

\subsection{Application of Microbial Fuels in Energy Conversion and Storage}

The production of liquid fuels and energy molecules as a form of biological energy storage is an attractive renewable energy option. Remarkable advances have been made during the last decade in the design and production of fuels and energy molecules using microbes. Still, there are a limited number of known metabolic pathways that produce hydrocarbon molecules relevant to fuel $[136,137]$. Thanks to their growing maturity and reduced price structure, the availability of renewable energy technologies is increasing significantly throughout the world. However, to increase the penetration of renewable sources into the grid, large-scale electrical energy storage and retrieval would almost certainly be necessary.

The perfect combinations of high power and energy density, low economic and environmental costs, lack of site limitations, long period and calendar lifetime, convenient supply of materials, and quick reaction time are all required to ensure the quick and effective penetration of renewable fuel technologies to the grid. By allowing rewired carbon fixation, a method that spatially divides reactions typically performed together in a photosynthetic cell and substitutes the least effective with biological equivalents, engineered microbes could overcome many of the shortcomings of current energy storage technologies. If effective, this will allow the storage of renewable electricity at high density, including hydrocarbons and nonvolatile polymers, by the microbial or enzymatic fixation of carbon dioxide and subsequent delivery of materials as carbon-based energy storage molecules.

\subsection{Application of Microbial Fuels in a Built Environment}

In a similar way to energy conversion and storage, the application of bioenergy in built environments is a rapidly expanding field. However, there is not much information in the literature regarding the use of microbial communities in built environments. Lal et al. [138] reintroduced the concept of using microorganisms in homes for the self-generation of bioenergy through the processing of waste materials. However, they mentioned several challenges that will need to be resolved before this microbial technology can be feasibly used in homes. The initial investments cost is high, and the efficiency for the anaerobic digestion is low and requires further studies. Finally, few microbes have been discovered as potential electron generators, but next-generation sequencing technologies will enhance the discovery of new and efficient microorganisms. 


\section{Conclusions}

This review covered characteristics important for the microbial production of biofuels from waste. Researchers continue toward the identification of biological pretreatments of feedstock to generate high yields of advanced biofuels in a cost-effective manner. The challenge to achieving high production rates of advanced biofuels from biomass lies in the selection of the optimal microorganism and then the design of complete biomass degradation pathways in model microorganisms using the latest synthetic biology tools.

To produce cost-effective advanced biofuels, future work should be directed toward the waste-to-wheel life cycle assessment of various feedstocks, such as agriculture waste, OFMSW, and forest residue, as the lignocellulosic content would make a difference for the production rate, cost, and environmental impact. The commercialization of advanced biofuels requires the use of representative laboratory-scale processes to obtain theoretical productivity rates to be used and scaled up to industry-scale bioreactors.

Genomic databases can be mined to identify novel pathways for polyketide-derived fuels and fuel molecules from the isoprenoids, as well as enzyme expression under varying lignocellulosic content biomass, to provide for a complete insight into the techno-economic feasibility of biosynthetic biofuels. More emphasis needs to be placed on the development of bioenergy molecules and renewable fuels from organic municipal solid waste using synthetic biology.

The source of biomass plays a significant role in fuel production. MSW is a sustainable source for a feedstock; however, extraction of the lignocellulosic material necessitated energy for mechanical and heat separation, which increases the cost and environmental impact. n-Butanol was shown to be an attractive choice regarding economic and environmental assessment, and it could be a replacement for bioethanol and could be used as a gasoline additive in the infrastructure of current engines. Fatty alcohol and alkanes can be appropriate replacements for diesel and jet fuels, respectively, as well as additives for the present engines, if the production rate was significantly increased.

Some other additional recommendations include:

- The early separation of OFMSW from commercial and demotic buildings will avoid some processes, such as autoclaving, and gain more lignocellulosic material, leading to the greater production of biofuels with less production cost;

- Greater attention should be given to residues with the most lignocellulosic content as a sustainable feedstock for microbial fuels;

- Enzymatic pretreatment appeared to be one of the most appropriate pretreatment methods, as it requires minimal chemical additives, low energy consumption, and a short reaction time;

- Pentose and simple sugar utilization and lignin management should be essential considerations in plants of the next generation;

- Efforts for laboratory studies should be guided in this field by employing genetic engineering techniques to selected species of organisms.

Author Contributions: Conceptualization, U.A. and H.H.H.; methodology, U.A. and H.H.H.; validation, H.H.H.; formal analysis, U.A.; investigation, U.A., H.H.H. and V.O.; resources, U.A.; data curation, U.A.; writing—original draft preparation, U.A.; writing—review and editing, U.A., H.H.H. and V.O.; visualization, U.A. and V.O.; project administration, U.A.; funding acquisition, U.A. and H.H.H. All authors have read and agreed to the published version of the manuscript.

Funding: This work was funded by the Royal Society grant for the International Exchanges Scheme (Project number IES $\backslash$ R2 $\backslash 192108$ ).

Conflicts of Interest: The authors declare no conflict of interest. 


\section{References}

1. International Energy Agency. Net Zero by 2050-a Roadmap for the Global Energy Sector. Special Report. Available online: https:/ / www.iea.org/reports/net-zero-by-2050 (accessed on 18 August 2021).

2. Zhang, F.; Rodriguez, S.; Keasling, J. Metabolic engineering of microbial pathways for advanced biofuels production. Curr. Opin. Biotechnol. 2011, 22, 775-783. [CrossRef]

3. Harvey, B.; Meylemans, H. The role of butanol in the development of sustainable fuel technologies. J. Chem. Technol. Biotechnol. 2010, 86, 2-9. [CrossRef]

4. Sims, R.; Mabee, W.; Saddler, J.; Taylor, M. An overview of second-generation biofuel technologies. Bioresour. Technol. 2010, 101, 1570-1580. [CrossRef]

5. Harvey, B.; Meylemans, H.; Gough, R.; Quintana, R.; Garrison, M.; Bruno, T. High-density biosynthetic fuels: The intersection of heterogeneous catalysis and metabolic engineering. Phys. Chem. Chem. Phys. 2014, 16, 9448-9457. [CrossRef] [PubMed]

6. Liao, J.; Mi, L.; Pontrelli, S.; Luo, S. Fuelling the future: Microbial engineering for the production of sustainable biofuels. Nat. Rev. Microbiol. 2016, 14, 288-304. [CrossRef]

7. Searle, S.; Malins, C. Waste and residue availability for advanced biofuel production in EU Member States. Biomass Bioenergy 2016, 89, 2-10. [CrossRef]

8. Uçkun Kiran, E.; Trzcinski, A.; Ng, W.; Liu, Y. Bioconversion of food waste to energy: A review. Fuel 2014, 134, 389-399. [CrossRef]

9. Saini, R.; Hegde, K.; Kaur Brar, S.; Vezina, P. Advanced biofuel production and road to commercialization: An insight into bioconversion potential of Rhodosporidium sp. Biomass Bioenergy 2020, 132, 105439. [CrossRef]

10. Howard, T.P.; Middelhaufe, S.; Moore, K.; Edner, C.; Kolak, D.M.; Taylor, G.N.; Parker, D.A.; Lee, R.; Smirnoff, N.; Aves, S.J.; et al. Synthesis of customized petroleum-replica fuel molecules by targeted modification of free fatty acid pools in Escherichia coli. Proc. Natl. Acad. Sci. USA 2013, 110, 7636-7641. [CrossRef]

11. Fulton, L.; Lynd, L.; Körner, A.; Greene, N.; Tonachel, L. The need for biofuels as part of a low carbon energy future. Biofuel Bioprod. Biorefin. 2015, 9, 476-483. [CrossRef]

12. Peralta-Yahya, P.; Zhang, F.; del Cardayre, S.; Keasling, J. Microbial engineering for the production of advanced biofuels. Nature 2012, 488, 320-328. [CrossRef] [PubMed]

13. Cheon, S.; Kim, H.; Gustavsson, M.; Lee, S. Recent trends in metabolic engineering of microorganisms for the production of advanced biofuels. Curr. Opin. Chem. Biol. 2016, 35, 10-21. [CrossRef] [PubMed]

14. Lee, S.; Chou, H.; Ham, T.; Lee, T.; Keasling, J. Metabolic engineering of microorganisms for biofuels production: From bugs to synthetic biology to fuels. Curr. Opin. Biotechnol. 2008, 19, 556-563. [CrossRef] [PubMed]

15. Tripathi, N.; Hills, C.D.; Singh, R.S.; Atkinson, C.J. Biomass waste utilisation in low-carbon products: Harnessing a major potential resource. Climate and Atmospheric Science 2019, 2, 35. [CrossRef]

16. Li, A.; Antizar-Ladislao, B.; Khraisheh, M. Bioconversion of municipal solid waste to glucose for bio-ethanol production. Bioprocess. Biosyst. Eng. 2007, 30, 189-196. [CrossRef] [PubMed]

17. Kwon, S.W.; Paari, K.A.; Malaviya, A.; Jang, Y.S. Synthetic Biology Tools for Genome and Transcriptome Engineering of Solventogenic Clostridium. Front. Bioeng. Biotechnol. 2020, 8, 282. [CrossRef] [PubMed]

18. Köpke, M.; Held, C.; Hujer, S.; Liesegang, H.; Wiezer, A.; Wollherr, A.; Ehrenreich, A.; Liebl, W.; Gottschalk, G.; Dürre, P. Clostridium ljungdahlii represents a microbial production platform based on syngas. Proc. Natl. Acad Sci. USA 2010, 107, 13087-13092. [CrossRef]

19. Kirby, J.; Keasling, J.D. Biosynthesis of plant isoprenoids: Perspectives for microbial engineering. Annu. Rev. Plant. Biol. 2009, 60, 335-355. [CrossRef]

20. Harvey, B.; Wright, M.; Quintana, R. High-density renewable fuels based on the selective dimerization of pinenes. Energy Fuels 2010, 24, 267-273. [CrossRef]

21. Yuzawa, S.; Kim, W.; Katz, L.; Keasling, J. Heterologous production of polyketides by modular type I polyketide synthases in Escherichia coli. Curr. Opin. Biotechnol. 2012, 23, 727-735. [CrossRef]

22. Hwang, S.; Lee, N.; Cho, S.; Palsson, B.; Cho, B.K. Repurposing Modular Polyketide Synthases and Non-ribosomal Peptide Synthetases for Novel Chemical Biosynthesis. Front. Mol. Biosci. 2020, 7, 87. [CrossRef]

23. Shaw, A.J.; Lam, F.H.; Hamilton, M.; Consiglio, A.; MacEwen, K.; Brevnova, E.E.; Greenhagen, E.; LaTouf, W.G.; South, C.R.; van Dijken, H.; et al. Metabolic engineering of microbial competitive advantage for industrial fermentation processes. Science 2016, 353, 583-586. [CrossRef] [PubMed]

24. Westfall, P.; Gardner, T. Industrial fermentation of renewable diesel fuels. Curr. Opin. Biotechnol. 2011, 22, 344-350. [CrossRef] [PubMed]

25. Brown, S.; Loh, J.; Aves, S.J.; Howard, T.P. Alkane biosynthesis in bacteria. Biogenesis of Hydrocarbons. In Handbook of Hydrocarbon and Lipid Microbiology; Stams, A., Sousa, D., Eds.; Springer: Cham, Switzerland, 2019. [CrossRef]

26. Jovanovic Tews, I.; Jones, S.B.; Santosa, D.M.; Ziyu, D.; Ramasamy, K.; Zhu, Y. A survey of opportunities for microbial conversion of biomass to hydrocarbon compatible fuels. Pac. Northwest Natl. Lab. 2010, 19704, 01-33.

27. Li, Q.; Cai, H.; Hao, B.; Zhang, C.; Yu, Z.; Zhou, S.; Chenjuan, L. Enhancing Clostridial acetone-butanol-ethanol (ABE) production and improving fuel properties of ABE-enriched biodiesel by extractive fermentation with biodiesel. Appl. Biochem. Biotechnol. 2010, 162, 2381-2386. [CrossRef] 
28. Alper, H.; Moxley, J.; Nevoigt, E.; Fink, G.; Stephanopoulos, G. Engineering yeast transcription machinery for improved ethanol tolerance and production. Science 2006, 314, 1565-1568. [CrossRef]

29. Song, X.; Yu, H.; Zhu, K. Improving alkane synthesis in Escherichia coli via metabolic engineering. Appl. Microbiol. Biotechnol. 2015, 100, 757-767. [CrossRef]

30. Ezeji, T.; Qureshi, N.; Blaschek, H.P. Bioproduction of butanol from biomass: From genes to bioreactors. Curr. Opin. Biotechnol. 2007, 18, 220-227. [CrossRef]

31. Ladygina, N.; Dedyukhina, E.G.; Vainshtein, M.B. A review on microbial synthesis of hydrocarbons. Process Biochem. 2006, 41, 1001-1014. [CrossRef]

32. Davison, J. Genetic exchange between bacteria in the environment. Plasmid 1999, 42, 73-91. [CrossRef]

33. Torres, B.; Garcia, J.; Diaz, E. Plasmids as tools for containment. In Plasmid Biology; Funnell, B., Phillips, G., Eds.; ASM: Washington, DC, USA, 2003; pp. 589-601.

34. Davison, J. Genetic tools for Pseudomonads, Rhizobia and other Gram-negative bacteria. Biotechniques 2002, 32, 386-401. [CrossRef]

35. Davison, J. Towards safer vectors for field release of recombinant bacteria. Environ. Biosafety Res. 2002, 1, 9-18. [CrossRef]

36. Secretariat of the Convention on Biological Diversity (2000). Cartagena Protocol on Biosafety to the Convention on Biological Diversity: Text and annexes. Montreal 2000, 1-19, ISBN 92-807-1924-6.

37. Food and Agriculture Organisation of the United Nations. International Plant Protection Convention. Available online: https: / / www.ippc.int/en/ (accessed on 31 August 2021).

38. Andrianantoandro, E.; Basu, S.; Karig, D.; Weiss, R. Synthetic biology: New engineering rules for an emerging discipline. Mol. Syst. Biol. 2006, 2, 1744-4292. [CrossRef] [PubMed]

39. Pfleger, B.F.; Pitera, D.J.; Smolke, C.D.; Keasling, J.D. Combinatorial engineering of intergenic regions in operons tunes expression of multiple genes. Nat. Biotechnol. 2006, 24, 1027-1032. [CrossRef]

40. Li, M.; Elledge, S. Harnessing homologous recombination in vitro to generate recombinant DNA via SLIC. Nat. Methods 2007, 4, 251-256. [CrossRef]

41. Shetty, R.; Endy, D.; Knight, T. Engineering BioBrick vectors from BioBrick parts. J. Biol. Eng. 2008, 2, 5. [CrossRef]

42. Carbonell, P.; Le Feuvre, R.; Takano, E.; Scrutton, N.S. In silico design and automated learning to boost next-generation smart biomanufacturing. Synth. Biol. 2020, 5, ysaa020. [CrossRef] [PubMed]

43. Gupta, P.; Phulara, S.C. Metabolic engineering for isoprenoid-based biofuel production. J. Appl. Microbiol. 2015, 119, 605-619. [CrossRef] [PubMed]

44. Hull, A.; Golubkov, I.; Kronberg, B.; Marandzheva, T.; van Stam, J. An alternative fuel for spark ignition engines. Int. J. Engine Res. 2006, 7, 203-214. [CrossRef]

45. Withers, S.; Gottlieb, S.; Lieu, B.; Newman, J.; Keasling, J. Identification of isopentenol biosynthetic genes from Bacillus subtilis by a screening method based on isoprenoid precursor toxicity. Appl. Environ. Microbiol. 2007, 73, 6277-6283. [CrossRef] [PubMed]

46. Wang, C.; Yoon, S.H.; Shah, A.A.; Chung, Y.R.; Kim, J.Y.; Choi, E.S.; Keasling, J.D.; Kim, S.W. Farnesol production from Escherichia coli by harnessing the exogenous mevalonate pathway. Biotechnol. Bioeng. 2010, 107, 421-429. [CrossRef]

47. Meadows, C.; Kang, A.; Lee, T. Metabolic engineering for advanced biofuels production and recent advances toward commercialization. Biotechnol. J. 2018, 13, 1600433. [CrossRef]

48. Dugar, D.; Stephanopoulos, G. Relative potential of biosynthetic pathways for biofuels and bio-based products. Nat. Biotechnol. 2011, 29, 1074-1078. [CrossRef]

49. Krishnan, A.; Bonnie, A.; McNeil, B.A.; Stuart, D.T. Biosynthesis of Fatty Alcohols in Engineered Microbial Cell Factories: Advances and Limitations. Front. Bioeng. Biotechnol. 2020, 8, 610936. [CrossRef]

50. Röttig, A.; Wenning, L.; Bröker, D.; Steinbüchel, A. Fatty acid alkyl esters: Perspectives for production of alternative biofuels. Appl. Microbiol. Biotechnol. 2009, 85, 1713-1733. [CrossRef] [PubMed]

51. Lennen, R.; Braden, D.; West, R.; Dumesic, J.; Pfleger, B. A process for microbial hydrocarbon synthesis: Overproduction of fatty acids in Escherichia coli and catalytic conversion to alkanes. Biotechnol. Bioeng. 2010, 106, 193-202. [CrossRef] [PubMed]

52. Liu, T.; Vora, H.; Khosla, C. Quantitative analysis and engineering of fatty acid biosynthesis in E. coli. Metab. Eng. 2010, 12, 378-386. [CrossRef]

53. Pfleger, B.F.; Gossing, M.; Nielsen, J. Metabolic engineering strategies for microbial synthesis of oleochemicals. Metab. Eng. 2015, 29, 1-11. [CrossRef] [PubMed]

54. Fujita, Y.; Matsuoka, H.; Hirooka, K. Regulation of fatty acid metabolism in bacteria. Mol. Microbiol. 2007, 66, 829-839. [CrossRef]

55. Zhang, F.; Carothers, J.M.; Keasling, J.D. Design of a dynamic sensor-regulator system for production of chemicals and fuels derived from fatty acids. Nat. Biotechnol. 2012, 30, 354-359. [CrossRef] [PubMed]

56. Liu, H.; Yu, C.; Feng, D.; Cheng, T.; Meng, X.; Liu, W.; Zou, H.; Xian, M. Production of extracellular fatty acid using engineered Escherichia coli. Microb. Cell Fact. 2012, 11, 41. [CrossRef]

57. Dellomonaco, C.; Clomburg, J.M.; Miller, E.N.; Gonzalez, R. Engineered reversal of the beta-oxidation cycle for the synthesis of fuels and chemicals. Nature 2011, 476, 355-359. [CrossRef] [PubMed]

58. Xiao, Y.; Bowen, C.H.; Liu, D.; Zhang, F.Z. Exploiting nongenetic cell-to-cell variation for enhanced biosynthesis. Nat. Chem. Biol. 2016, 12, 339-344. [CrossRef] [PubMed]

59. Rude, M.; Schirmer, A. New microbial fuels: A biotech perspective. Curr. Opin. Microbiol. 2009, 12, 274-281. [CrossRef] 
60. Beller, H.; Goh, E.; Keasling, J. Genes involved in long-chain alkene biosynthesis in Micrococcus luteus. Appl. Environ. Microbiol. 2009, 76, 1212-1223. [CrossRef]

61. Schirmer, A.; Rude, M.A.; Li, X.; Popova, E.; del Cardayre, S.B. Microbial biosynthesis of alkanes. Science 2010, 329, 559-562. [CrossRef] [PubMed]

62. Rude, M.; Baron, T.; Brubaker, S.; Alibhai, M.; del Cardayre, S.; Schirmer, A. Terminal olefin (1-alkene) biosynthesis by a novel P450 Fatty Acid Decarboxylase from Jeotgalicoccus Species. Appl. Environ. Microbiol. 2011, 77, 1718-1727. [CrossRef]

63. Jiménez-Díaz, L.; Caballero, A.; Pérez-Hernández, N.; Segura, A. Microbial alkane production for jet fuel industry: Motivation, state of the art and perspectives. Microb. Biotechnol. 2016, 10, 103-124. [CrossRef]

64. Rabinovitch-Deere, C.A.; Oliver, J.W.K.; Rodriguez, G.M.; Atsumi, S. Synthetic biology and metabolic engineering approaches to produce biofuels. Chem. Rev. 2013, 113, 4611-4632. [CrossRef]

65. Atsumi, S.; Cann, A.F.; Connor, M.R.; Shen, C.R.; Smith, K.M.; Brynildsen, M.P.; Chou, K.J.; Hanai, T.; Liao, J.C. Metabolic engineering of Escherichia coli for 1-butanol production. Metab. Eng. 2008, 10, 305-311. [CrossRef] [PubMed]

66. Atsumi, S.; Wu, T.Y.; Eckl, E.M.; Hawkins, S.D.; Buelter, T.; Liao, J.C. Engineering the isobutanol biosynthetic pathway in Escherichia coli by comparison of three aldehyde reductase/alcohol dehydrogenase genes. Appl. Microbiol. Biotechnol. 2010, 85, 651-657. [CrossRef]

67. Bastian, S.; Liu, X.; Meyerowitz, J.T.; Snow, C.D.; Chen, M.M.Y.; Arnold, F.H. Engineered ketol-acid reductoisomerase and alcohol dehydrogenase enable anaerobic 2-methylpropan1-ol production at theoretical yield in Escherichia coli. Metab. Eng. 2011, 13, 345-352. [CrossRef] [PubMed]

68. Shen, C.R.; Lan, E.I.; Dekishima, Y.; Baez, A.; Cho, K.M.; Liao, J.C. Driving forces enable hightiter anaerobic 1-butanol synthesis in Escherichia coli. Appl. Environ. Microbiol. 2011, 77, 2905-2915. [CrossRef]

69. Lian, J.Z.; Si, T.; Nair, N.U.; Zhao, H.M. Design and construction of acetyl-CoA overproducing Saccharomyces cerevisiae strains Metab. Eng. 2014, 24, 139-149. [CrossRef]

70. Si, T.; Luo, Y.Z.; Xiao, H.; Zhao, H.M. Utilizing an endogenous pathway for 1- butanol production in Saccharomyces cerevisiae. Metab. Eng. 2014, 22, 60-68. [CrossRef] [PubMed]

71. Gleizer, S.; Ben-Nissan, R.; Bar-On, Y.M.; Antonovsky, N.; Noor, E.; Zohar, Y.; Jona, G.; Krieger, E.; Shamshoum, M.; Bar-Even, A.; et al. Conversion of Escherichia coli to generate all biomass carbon from $\mathrm{CO}_{2}$. Cell 2019, 179, 1255-1263. [CrossRef] [PubMed]

72. Woo, J.E.; Jang, Y.S. Metabolic engineering of microorganisms for the production of ethanol and butanol from oxides of carbon. Appl. Microbiol. Biotechnol. 2019, 103, 8283-8292. [CrossRef]

73. Antonovsky, N.; Gleizer, S.; Noor, E.; Zohar, Y.; Herz, E.; Barenholz, U.; Zelcbuch, L.; Amram, S.; Wides, A.; Tepper, N.; et al. Sugar synthesis from $\mathrm{CO}_{2}$ in Escherichia coli. Cell 2016, 166, 115-125. [CrossRef]

74. Guadalupe-Medina, V.; Wisselink, H.W.; Luttik, M.A.; de Hulster, E.; Daran, J.M.; Pronk, J.T.; van Maris, A.J. Carbon dioxide fixation by Calvin-Cycle enzymes improves ethanol yield in yeast. Biotechnol. Biofuels 2013, 6, 125. [CrossRef]

75. Li, H.; Opgenorth, P.H.; Wernick, D.G.; Rogers, S.; Wu, T.Y.; Higashide, W.; Malati, P.; Huo, Y.X.; Cho, K.M.; Liao, J.C. Integrated electromicrobial conversion of $\mathrm{CO}_{2}$ to higher alcohols. Science 2012, 335, 1596. [CrossRef]

76. Atsumi, S.; Hanai, T.; Liao, J. Non-fermentative pathways for synthesis of branched-chain higher alcohols as biofuels. Nature 2008, 451, 86-89. [CrossRef]

77. Larson, E.D. Biofuel Production Technologies: Status, Prospects and Implications for Trade and Development; United Nations Conference on Trade and Development (UNCTAD): New York, NY, USA, 2008.

78. Sánchez, O.J.; Cardona, C.A. Trends in biological production of fuel ethanol from different feedstocks. Bioresour Technol. 2008, 99, 5270-5295. [CrossRef] [PubMed]

79. Hosseini Koupaie, E.; Dahadha, S.; Bazyar Lakeh, A.A.; Azizi, A.; Elbeshbishy, E. Enzymatic pretreatment of lignocellulosic biomass for enhanced biomethane production-A review. J. Environ. Manag. 2019, 233, 774-784. [CrossRef]

80. Taherzadeh, M.J.; Karimi, K. Pretreatment of lignocellulosic wastes to improve ethanol and biogas production: A review. Int. J. Mol. Sci. 2008, 9, 1621-1651. [CrossRef]

81. Saritha, M.; Arora, A.; Lata. Biological pretreatment of lignocellulosic substrates for enhanced delignification and enzymatic digestibility. Indian J. Microbiol. 2011, 52, 122-130. [CrossRef] [PubMed]

82. Ge, H.; Jensen, P.; Batstone, D. Pre-treatment mechanisms during thermophilic-mesophilic temperature phased anaerobic digestion of primary sludge. Water Res. 2010, 44, 123-130. [CrossRef] [PubMed]

83. Alvira, P.; Tomás-Pejó, E.; Ballesteros, M.; Negro, M. Pretreatment technologies for an efficient bioethanol production process based on enzymatic hydrolysis: A review. Bioresour Technol. 2010, 101, 4851-4861. [CrossRef]

84. Sharma, H.; Xu, C.; Qin, W. Biological pretreatment of lignocellulosic biomass for biofuels and bioproducts: An overview. Waste Biomass Valorization 2017, 10, 235-251. [CrossRef]

85. Mishra, S.; Singh, P.K.; Dash, S.; Pattnaik, R. Microbial pretreatment of lignocellulosic biomass for enhanced biomethanation and waste management. 3 Biotech 2018, 8, 458. [CrossRef]

86. Zheng, Y.; Zhao, J.; Xu, F.; Li, Y. Pretreatment of lignocellulosic biomass for enhanced biogas production. Prog. Energy Combust. Sci. 2014, 42, 35-53. [CrossRef]

87. Isroi, I.; Millati, R.; Syamsiah, S.; Niklasson, C.; Cahyanto, M.N.; Ludquist, K. Biological pretreatment of lignocelluloses with white-rot fungi and its applications: A review. BioResources 2011, 6, 5224-5259. [CrossRef] 
88. Patel, H.; Gupte, A.; Gupte, S. Effect of different culture conditions and inducers on production of laccase by a basidiomycete fungal isolate Pleurotus ostreatus HP-1 under solid state fermentation. BioResources 2009, 4, 268-284.

89. Romano, R.; Zhang, R.; Teter, S.; McGarvey, J. The effect of enzyme addition on anaerobic digestion of Jose Tall Wheat Grass. Bioresour. Technol. 2009, 100, 4564-4571. [CrossRef]

90. Yunqin, L.; Dehan, W.; Lishang, W. Biological pretreatment enhances biogas production in the anaerobic digestion of pulp and paper sludge. Waste Manag. Res. 2010, 28, 800-810. [CrossRef]

91. Ziemiński, K.; Romanowska, I.; Kowalska, M. Enzymatic pretreatment of lignocellulosic wastes to improve biogas production. Waste Manag. 2012, 32, 1131-1137. [CrossRef] [PubMed]

92. Sun, Y.; Cheng, J. Hydrolysis of lignocellulosic materials for ethanol production: A review. Bioresour. Technol. 2002, 83, 1-11. [CrossRef]

93. Mackul'ak, T.; Prousek, J.; Švorc, L'.; Drtil, M. Increase of biogas production from pretreated hay and leaves using wood-rotting fungi. Chem. Papers 2012, 66, 649-653. [CrossRef]

94. Tangnu, S.; Blanch, H.; Wilke, C. Enhanced production of cellulase, hemicellulase, and ?-glucosidase by Trichoderma reesei (Rut C-30). Biotechnol. Bioeng. 1981, 23, 1837-1849. [CrossRef]

95. Shi, J.; Sharma-Shivappa, R.; Chinn, M.; Howell, N. Effect of microbial pretreatment on enzymatic hydrolysis and fermentation of cotton stalks for ethanol production. Biomass Bioenergy 2009, 33, 88-96. [CrossRef]

96. Liu, J.; Wang, M.; Tonnis, B.; Habteselassie, M.; Liao, X.; Huang, Q. Fungal pretreatment of switchgrass for improved saccharification and simultaneous enzyme production. Bioresour. Technol. 2013, 135, 39-45. [CrossRef] [PubMed]

97. Silveira, M.H.L.; Morais, A.R.C.; da Costa Lopes, A.M.; Olekszyszen, D.N.; Bogel-Łukasik, R.; Andreaus, J.; Pereira Ramos, L. Current pretreatment technologies for the development of cellulosic ethanol and biorefineries. ChemSusChem 2015, 8, 3366-3390. [CrossRef]

98. Ma, F.; Yang, N.; Xu, C.; Yu, H.; Wu, J.; Zhang, X. Combination of biological pretreatment with mild acid pretreatment for enzymatic hydrolysis and ethanol production from water hyacinth. Bioresour. Technol. 2010, 101, 9600-9604. [CrossRef] [PubMed]

99. Shirkavand, E.; Baroutian, S.; Gapes, D.J.; Young, B.R. Combination of fungal and physicochemical processes for lignocellulosic biomass pretreatment-a review. Renew. Sustain. Energy Rev. 2016, 54, 217-234. [CrossRef]

100. Shi, Y.; Chai, L.; Tang, C.; Yang, Z.; Zhang, H.; Chen, R.; Chen, Y.; Zheng, Y. Characterization and genomic analysis of kraft lignin biodegradation by the beta-proteobacterium Cupriavidus basilensis B-8. Biotechnol. Biofuels 2013, 6, 1. [CrossRef] [PubMed]

101. Chen, Y.; Chai, L.; Tang, C.; Yang, Z.; Zheng, Y.; Shi, Y.; Zhang, H. Kraft lignin biodegradation by Novosphingobium sp. B-7 and analysis of the degradation process. Bioresour. Technol. 2012, 123, 682-685. [CrossRef]

102. Zhuo, S.; Yan, X.; Liu, D.; Si, M.; Zhang, K.; Liu, M.; Peng, B.; Shi, Y. Use of bacteria for improving the lignocellulose biorefinery process: Importance of pre-erosion. Biotechnol. Biofuels 2018, 11, 146. [CrossRef]

103. Masai, E.; Katayama, Y.; Fukuda, M. Genetic and biochemical investigations on bacterial catabolic pathways for lignin-derived aromatic compounds. Biosci. Biotechnol. Biochem. 2007, 71, 1-15. [CrossRef]

104. Maki, M.; Leung, K.T.; Qin, W. The prospects of cellulase-producing bacteria for the bioconversion of lignocellulosic biomass. Int. J. Biol. Sci. 2009, 5, 500-516. [CrossRef] [PubMed]

105. Miron, J.; Ben-Ghedalia, D.; Morrison, M. Invited review: Adhesion mechanisms of rumen cellulolytic bacteria. J. Dairy Sci. 2001, 84, 1294-1309. [CrossRef]

106. Duff, S.; Murray, W. Bioconversion of forest products industry waste cellulosics to fuel ethanol: A review. Bioresour. Technol. 1996, 55, 1-33. [CrossRef]

107. Dien, B.; Cotta, M.; Jeffries, T. Bacteria engineered for fuel ethanol production: Current status. Appl. Microbiol. Biotechnol. 2003, 63, 258-266. [CrossRef] [PubMed]

108. Xia, J.; Yang, Y.; Liu, C.C.; Yang, S.; Feng-Wu Bai, F.W. Engineering Zymomonas mobilis for Robust Cellulosic Ethanol Production. Trends Biotechnol. 2019, 37, 960. [CrossRef]

109. de Gonzalo, G.; Colpa, D.; Habib, M.; Fraaije, M. Bacterial enzymes involved in lignin degradation. J. Biotechnol. 2016, 236, 110-119. [CrossRef]

110. Chandra, R.; Chowdhary, P. Properties of bacterial laccases and their application in bioremediation of industrial wastes. Environ. Sci. Process. Impacts 2015, 17, 326-342. [CrossRef]

111. Picart, P.; de María, P.; Schallmey, A. From gene to biorefinery: Microbial $\beta$-etherases as promising biocatalysts for lignin valorization. Front. Microbiol. 2015, 6, 00916. [CrossRef]

112. Bala, R.; Mondal, M. Study of biological and thermo-chemical pretreatment of organic fraction of municipal solid waste for enhanced biogas yield. Environ. Sci. Pollut. Res. 2019, 27, 27293-27304. [CrossRef]

113. Xu, S.; Kong, X.; Liu, J.; Zhao, K.; Zhao, G.; Bahdolla, A. Effects of high-pressure extruding pretreatment on MSW upgrading and hydrolysis enhancement. Waste Manag. 2016, 58, 81-89. [CrossRef] [PubMed]

114. Bala, R.; Gautam, V.; Mondal, M. Improved biogas yield from organic fraction of municipal solid waste as preliminary step for fuel cell technology and hydrogen generation. Int. J. Hydrogen Energy 2019, 44, 164-173. [CrossRef]

115. Li, Y.; Jin, Y. Effects of thermal pretreatment on acidification phase during two-phase batch anaerobic digestion of kitchen waste. Renew. Energy 2015, 77, 550-557. [CrossRef]

116. Fdez.-Güelfo, L.; Álvarez-Gallego, C.; Sales Márquez, D.; Romero García, L. Biological pretreatment applied to industrial organic fraction of municipal solid wastes (OFMSW): Effect on anaerobic digestion. Chem. Eng. J. 2011, 172, 321-325. [CrossRef] 
117. Tyagi, V.; Lo, S.; Rajpal, A. Chemically coupled microwave and ultrasonic pre-hydrolysis of pulp and paper mill waste-activated sludge: Effect on sludge solubilisation and anaerobic digestion. Environ. Sci. Pollut. Res. 2014, 21, 6205-6217. [CrossRef]

118. Rudakiya, D.; Gupte, A. Degradation of hardwoods by treatment of white rot fungi and its pyrolysis kinetics studies. Int. Biodeterior. Biodegrad. 2017, 120, 21-35. [CrossRef]

119. Fdez-Güelfo, L.; Álvarez-Gallego, C.; Sales, D.; Romero, L. The use of thermochemical and biological pretreatments to enhance organic matter hydrolysis and solubilization from organic fraction of municipal solid waste (OFMSW). Chem. Eng. J. 2011, 168, 249-254. [CrossRef]

120. Cammarota, M.; Teixeira, G.; Freire, D. Enzymatic pre-hydrolysis and anaerobic degradation of wastewaters with high oil contents. Biotechnol. Lett. 2001, 23, 1591-1595. [CrossRef]

121. Koltermann, A.; Kraus, M.; Rarbach, M.; Reisinger, C.; Zavrel, M.; Soltl, Y. Cellulosic ethanol from agricultural residues-an advanced biofuel and biobased chemical platform. JSM Biotechnol. Bioeng. 2014, 2, 1024.

122. Verma, A.; Kumar, S.; Jain, P.K. Key pre-treatment technologies on cellulosic ethanol production. J. Sci. Res. 2011, 55 , 57-63.

123. Kumar, P.D.; Barrett, D.M.; Delwiche, M.J.; Stroeve, P. Methods for pretreatment of lignocellulosic biomass for efficient hydrolysis and biofuel production. Ind. Eng. Chem. Res. 2009, 48, 3713-3729. [CrossRef]

124. Lee, J. Biological conversion of lignocellulosic biomass to ethanol. J. Biotechnol. 1997, 56, 1-24. [CrossRef] [PubMed]

125. Ray, M.J.; Leak, D.J.; Spanu, P.D.; Murphy, R.J. Brown rot fungal early stage decay mechanism as a biological pretreatment for softwood biomass in biofuel production. Biomass Bioenerg. 2010, 34, 1257-1262. [CrossRef]

126. Sanchez, C. Lignocellulosic residues: Biodegradation and bioconversion by fungi. Biotechnol. Adv. 2009, 27, 185-194. [CrossRef] [PubMed]

127. Dashtban, M.; Schraft, H.; Qin, W. Fungal bioconversion of lignocellulosic residues; Opportunities \& perspectives. Int. J. Biol Sci. 2009, 5, 578-595. [CrossRef] [PubMed]

128. Saravanakumar, K.; Kathiresan, K. Bioconversion of lignocellulosic waste to bioethanol by Trichoderma and yeast fermentation. Biotech 2013, 4, 493-499. [CrossRef] [PubMed]

129. Balasubramaniam, M.K.; Rajarathinam, R. Implementation of white rot fungal pretreated rice straw for sustainable bioethanol production by Saccharomyces cerevisiae. Int. J. Eng. Res. Technol. 2013, 2, 4047-4053.

130. Eggeman, T.; Elander, R.T. Process and economic analysis of pretreatment technologies. Bioresour. Technol. 2005, 96, 2019-2025. [CrossRef] [PubMed]

131. Amin, F.R.; Khalid, H.; Zhang, H.; Rahman, S.; Zhang, R.; Liu, G.; Chen, C. Pretreatment methods of lignocellulosic biomass for anaerobic digestion. AMB Exp. 2017, 7, 72. [CrossRef] [PubMed]

132. Dehghani, M.; Karimi, K.; Sadeghi, M. Pretreatment of Rice Straw for the Improvement of Biogas Production. Energy Fuels 2015, 29, 3770-3775. [CrossRef]

133. Galbe, M.; Wallberg, O. Pretreatment for biorefineries: A review of common methods for efficient utilization of lignocellulosic materials. Biotechnol. Biofuels 2019, 12, 294. [CrossRef] [PubMed]

134. Baruah, J.; Nath, B.K.; Sharma, R.; Sachin Kumar, S.; Deka, R.C.; Baruah, D.C.; Kalita, E. Recent Trends in the Pretreatment of Lignocellulosic Biomass for Value-Added Products. Front. Energy Res. 2018, 6, 141. [CrossRef]

135. Anitescu, G.; Bruno, T.J. Liquid biofuels: Fluid properties to optimize feedstock selection, processing, refining/blending, storage/transportation, and combustion. Energy Fuels 2012, 26, 324-348. [CrossRef]

136. Keasling, J.D. Manufacturing molecules through metabolic engineering. Science 2010, 330, 1355-1358. [CrossRef]

137. Peralta-Yahya, P.P.; Ouellet, M.; Chan, R.; Mukhopadhyay, A.; Keasling, J.D.; Lee, T.S. Identification and microbial production of a terpene-based advanced biofuel. Nat. Commun. 2011, 2, 483. [CrossRef] [PubMed]

138. Lal, D. Microbes to Generate Electricity. Indian J. Microbiol. 2013, 53, 120-122. [CrossRef] [PubMed] 